\title{
Assessment of Solid Mineral to Soil Radioactivity Contamination Index in Selected Mining Sites and their Radiological Risk Indices to the Public
}

Ezekiel Oghenenyerhovwo Agbalagba ( $\sim$ agbalagba.ezekiel@fupre.edu.ng )

Federal University of Petroleum Resources Effurun https://orcid.org/0000-0001-9036-6484

Mohammed S. Chaanda

Federal University of Petroleum Resources, Effurun

Stephen Uloho U. Egarievwe

Alabama Agricultural and Mechanical University: Alabama A\&M University

\section{Research Article}

Keywords: Radioactivity, Mineral, Soil, Percentage contribution, Mining area.

Posted Date: June 11th, 2021

DOI: https://doi.org/10.21203/rs.3.rs-496856/v1

License: (c) (i) This work is licensed under a Creative Commons Attribution 4.0 International License.

Read Full License 


\title{
Assessment of Solid Mineral to Soil Radioactivity Contamination Index in selected Mining Sites and their Radiological Risk Indices to the Public
}

\author{
Ezekiel Oghenenyerhovwo Agbalagba ${ }^{1}$, Mohammed S. Chaanda ${ }^{2}$ and Stephen U.
} Egarievwe $^{3}$

\author{
${ }^{1}$ Department of Physics, College of Science, Federal University of Petroleum Resources, \\ Effurun, Nigeria agbalagba.ezekiel@ fupre.edu.ng \\ ${ }^{2}$ Department of Earth Sciences, College of Science, Federal University of Petroleum \\ Resources, Effurun, Nigeria \\ ${ }^{3}$ Nuclear Engineering and Radiological Science Center, Alabama A\&M University, Normal, \\ AL 35762, USA, stephen.egarievwe@aamu.edu
}

Corresponding author: agbalagba.ezekiel@ fupre.edu.ng (+2348037434510)

\begin{abstract}
This study examined the radioactivity levels of soil samples within selected solid mining sites in Nigeria using high purity germanium $(\mathrm{HpGe})$ detector. Sixty soil samples in all were collected from the ten solid mineral mining sites investigated and six samples were collected as control samples from non-mining environment for analyses. The results of the activity concentration values obtained for ${ }^{40} \mathrm{~K},{ }^{226} \mathrm{Ra}$ and ${ }^{232} \mathrm{Th}$ are $100.22 \mathrm{~Bq} \mathrm{~kg}^{-1}, 33.15 \mathrm{~Bq} \mathrm{~kg}^{-}$ ${ }^{1}$ and $77.31 \mathrm{~Bq} \mathrm{~kg}^{-1}$ respectively. The ${ }^{226} \mathrm{Ra}$ and ${ }^{40} \mathrm{~K}$ activities were found to be within the United Nation Scientific Committee on the Effects of Atomic Radiation (UNSCEAR) acceptable permissible limit, but the ${ }^{232} \mathrm{Th}$ mean value was above the permissible limit of $30 \mathrm{~Bq} \mathrm{~kg}{ }^{-1}$ for the public. In comparison, ${ }^{40} \mathrm{~K},{ }^{226} \mathrm{Ra}^{2}$ and ${ }^{232} \mathrm{Th}$ soil samples mean activity concentrations were higher than the control soil samples values by $48.6 \%, 43.7 \%$ and $62.3 \%$ respectively. The results of estimated radiation hazard indices indicate average values of $150.72 \mathrm{~Bq} \mathrm{~kg}^{-1}$, $68.40 \eta \mathrm{Gyh}^{-1}, \quad 83.65 \mu \mathrm{Svy}^{-1}$ and $\quad 454.70 \mu \mathrm{Svy}^{-1}$ for the Radium Equivalent $\left(\mathrm{Ra}_{\mathrm{eq}}\right)$, Absorbed Dose Rate (D), Dose Equivalent (AEDE) and Annual Gonadal Equivalent Dose (AGED) respectively. The mean values for External Hazard Indices (Hex, Hin), Representative Gamma index $\left(I_{\gamma}\right)$ and Excess Life Cancer Risk (ELCR) were 0.41, 0.50, 1.06 and $0.29 \times 10^{-3}$ respectively. The statistical analysis shows positive skewness.
\end{abstract}

Keywords: Radioactivity, Mineral, Soil, Percentage contribution, Mining area.

\subsection{Introduction}

Assessment of background radioactivity level plays a significant role in the protection of man from excessive radiation exposure (Abodunrin et al., 2017). Natural background radiation levels are likely to vary with human activities and natural processes, it may also change with locations due to different mineralogical, deformational and climatic factors responsible for the syngenetic processes for mineral formation. Although natural background radiation level is time dependent, it does not depend on any constant level, because it is terrestrial and cosmic induced (Ahmed et al., 2020). Radioactivity levels are evaluated as part of national and international survey at different areas and countries of the world, for radiation protection (Mane et al. 2014; Ugbede, 2020). 
1 Naturally occurring radionuclide materials (Norms) are inherent in many geologic materials and consequently encountered during geologically related activities. Since radioactive materials are prevalent in many minerals and soil formation and in the water that meets them, extraction and processing of these mineral resources that emanate from these sources exposes and raises the concentration of naturally occurring radionuclide in the environment (Avwiri, et al., 2012). Exposure to high radiation level causes a wide range of health problems such as cancer of the lung, bone and skin, kidney ailments and blood infections (Kessaratikoon, et al., 2013; UNSCEAR, 2016). Other problems associated with high exposure to ionizing radiations to health include; alteration in the structure and functions of the cells and organs, deterministic effect, stochastic effects, irritations, sensitization, embryonic effects, etc. The knowledge of radionuclide distribution in the environment is therefore of immense benefits in assessing the effects of radiation exposure, thus, monitoring of radioactive materials are of primary importance to man and for the protection of the environmental (Avwiri et al., 2012; Emelue et al., 2014: Dolchinkov and Nichev, 2017).

Most mineral deposits are associated with radionuclide like uranium, thorium and its' progenies. Primary uranium ore minerals when weathered, oxidized or decompose and form secondary uranium minerals which on interaction with groundwater drift and contaminate the soil, water and aquatic bodies, even some distance away from the original source (Aliyu et al., 2015). They are also found in conglomerates, shale, limestone, sediment and hydrocarbon (Xhixha et al., 2015). Because minerals are found in within a host rock, there is the tendency that the immediate soil when weathered these minerals are found content an appreciable amount of radionuclides found in these minerals due to radioactivity transfer. Soil radioactivity concentration is one of the main determinants of the natural occurring radiation (Agbalagba et al., 2012; Ugbede, 2020). Measurement of the radioactivity level of some rock samples, potential sources rocks of hydrocarbons have been conducted in different parts of the world (Silo et al., 2013; Guidotti et al., 2015). They reported that the radioactivity concentrations of the radionuclides from the eastern region were generally low compared to that of the other regions, but Th-232 was identified as the major contributor of the dose that can be received from the environment.

When minerals are disintegrated through either natural or anthropogenic processes, radionuclides are liberated into the soil by rain infiltration and percolation processes (Taskin et al., 2009). It has been established from previous studies that some of these soil and minerals such as monazite, pyrochlore and xenotime, which are obtained as byproducts of tin mining 
1 are radioactive, (Eroglu and Kabadayi 2013, Ekeocha, 2016; Kritsananuwet et al., 2015;

2 Omotehinse and Ako, 2019). Exposure to radiations emitted by some of these radioactive minerals is a major source of health hazards (Charro et al., 2013; Todorovic 2015). However, some of these mining sites had persons do business and living in hunts around them, which overtime have developed into hamlets and villages where elevated level of radiation has been recorded. Literatures abound on research works that have been undertaken to precisely quantify the amount of radioactivity levels in different soil and solid minerals found in Nigeria in recent time (Avwiri et al., 2010; Sadiq and Agba, 2011;Agbalagba et al., 2012; Ademola and Onyema, 2014; Azionu et al., 2019; Babatunde et al., 2019;) and some countries of the world for radiation protection (Ragheb, 2007; Belivermis, 2012; Charro et al., 2013; Kovacs et al., 2013; Santawamaitre et al., 2014; Guidotti et al., 2015; Milenkovic et al., 2015; Todorovic et al., 2015; Kavitha et al., 2016). In the Northern and Western Nigeria, a sizeable number of research work have been conducted in this regard (Ademola and Obed, 2012; Innocent et al., 2013; Ademola et al., 2014), while little or nothing has been done in the eastern region of the country with rich solid mineral present. It is worth mentioning that investigation on the level of dosage and excess level of radiation in the risk of cancer in this area has been reported in previous studies (Wahsha et al., 2016: Ugbede and Echeweozo 2017; Ugbede, 2020; Ugbede and Osahon, 2021). This has necessitated the focus of this research work on the Eastern region of Nigeria. Moreso, most of these studies focused on radioactivity concentration in solid mineral with little or no attention given to the measurement of radioactivity levels in the soil where the minerals are found and which the public make greater contact with for farming, building and other domestic uses.

The government of Nigeria in recent time are making deliberate efforts to revamp mining activities in these long abandoned mineral resources mining sites to boost the internally generated revenues (IGR) of these States and for regional developed and integration, though according to the Nigerian Mining Act (2007), all mineral resources regardless of where they are occurring it is under the control of the Federal Government. But the growing concern of the radiation safety and health status of those living and working within these mineral mining environments are always not put into consideration in the planning and implementation of mining companies and government. This lend credence to this research work, because results obtained will serve as baseline data in these study areas and data obtained shall be sources of reference for future radiological impact evaluation studies, serving as data base which may be incorporated to Nigeria Nuclear Regulatory Agency (NNRA) resources for National Planning. 


\subsection{Materials and Methods}

\subsection{Location of Study Area}

Mineral resources abound in different part of Nigeria, proper harnessing of the resources based on the host rocks as presented in the Figure 1, hence giving rise to the different types of mineral deposits as shown in Figure 2. To conform to international best practices is the greatest challenge of the industry (see Figure 2). This study was conducted in five Eastern Geopolitical Zone (Made up of Abia, Anambra, Ebonyi, Enugu and Imo States). The region lies between longitudes $7^{\circ} 6^{\prime \prime} \mathrm{E}$ and $7^{\circ} 54^{\prime \prime} \mathrm{E}$ and latitudes $5^{\circ} 56^{\prime \prime} \mathrm{N}$ and $6^{\circ} 52^{\prime \prime} \mathrm{N}$. It encompasses an area of about $7161 \mathrm{~km}^{2}$ with elevation ranging from $32.0 \mathrm{~m}$ to $590.2 \mathrm{~m}$ above mean sea level (Osimobi et al., 2018). The region has two main landforms viz; a high relief central zone with undulating hills and ridges and lowland area. The high relief zone is geologically associated with the syncline composed of Ajali Sandstone and Nsukka Formation, while the eastern lowland zone is associated with rocks of Asu River group, Eze Aku Shale group, Awgu/Ndeabor Shale group, Asata/Nkporo Shale group and parts of Mamu Formation (Osimobi et al., 2018).

\subsection{Sample Collection and Preparation Techniques}

Soil samples were collected from coal and silica mining sites in Ewe in arochukwu in Abia State, glass-sand mine in Mbara-Ozu sand sites in Ihiala in Anambra State, limestone and ironstone mine in Akpuoach and Ishiagu sites in Ebonyi State. Soil samples were also collected from bitumen, coal and gypsum mine Ezeagu, Udi and Aninri sites in Enugu State, and clay and kaolin mine Isu and Okigwe sites in Imo State. A total of forty-eight soil samples were collected in all, and one control sample each from a non-mineral mining location from the five states. The soil samples were collected at depths of 0 to $10 \mathrm{~cm}$ (which represents the soil permeability to particle settlement depth variation), within the different mineral mine sites in black paper bags (to prevent interaction with sunlight to avoid breaking down of the radionuclides present). The soil samples collected were spread on stainless still sheets at ambient temperature for seven days to dry in a controlled environment to prevent local dust contamination. Samples were further dried in an oven at regulated temperature of $60^{\circ} \mathrm{C}$ to attain a constant weight.

The dried samples were then grounded using mortar and pestle to pulverize form and then filtered using 100-mesh sieve. At each interval of pulverization, the pestle and mortar were clean using methylated spirited to avoid crossed contamination. The dried homogeneously pulverized samples with dry-weight of $250 \mathrm{~g}$ were filled in air tight cylindrical plastic container 
1 (Marinelli beaker) that is of the detector geometry, and stored for a period of 28 days before counting to allow for secular equilibrium to be attained between ${ }^{226} \mathrm{Ra}$ and its short lived ${ }^{222} \mathrm{Rn}$ progeny (Zarie and Al Mugren, 2010;Avwiri et al., 2012; Ononugb et al., 2017; Wang, et al., 2017; Ugbede, 2020).

\subsection{Radioactivity Analysis of Samples}

The soil samples analysis for the natural radionuclide concentration were carried out using a computerized $\gamma$-ray spectrometry system with high purity germanium (HpGe) detector. The relative efficiency of the detector system was $39 \%$ and resolution of $1.8 \mathrm{kev}$ at $1.33 \mathrm{MeV}$ of Co-60. The spectrometer was attached to conventional electronics connected to a multichannel analyzer (MCA) card installed in a laptop computer. MAESTRO-32 software program was deployed to accumulate and analyze the data of the natural radionuclides present in the samples. The detector is located inside a cylindrical lead shield of $5 \mathrm{~cm}$ x $24 \mathrm{~cm}$ x $60 \mathrm{~cm}$ geometry. The metal (lead) shield was lined with different coatings of copper, cadmium and Plexiglas, of thickness $3 \mathrm{~mm}$ each. A counting time of 10 hours was adopted from the system calibration result for the acquire samples spectral data.

The high resolution of the HpGe detector made it possible to identify many $\gamma$-rays of the analyzed samples. The radioactivity levels of the uranium series were obtained using $\gamma$-ray emissions of ${ }^{214} \mathrm{~Pb}$ at $351.9 \mathrm{keV}(35.9 \%)$ and ${ }^{214} \mathrm{Bi}$ at $609.3 \mathrm{keV}(44.9 \%)$, for the ${ }^{232} \mathrm{Th}$-series, the emissions of ${ }^{228} \mathrm{Ac}$ at $911 \mathrm{keV}(26.6 \%),{ }^{212} \mathrm{~Pb}$ at $238.6 \mathrm{keV}(43.2 \%)$ and ${ }^{208} \mathrm{Tl}$ at $583 \mathrm{keV}$ $(30.2 \%)$ and were used as the radionuclide emission probabilities of $\gamma_{p}$. The ${ }^{40} \mathrm{~K}$ activity levels was acquired straight from its emission line of $1460.8 \mathrm{keV}(10.7 \%)$. The background spectra measured were used to correct the computed sample activities concentration in accordance with standard procedures (Zarie and Al Mugren, 2010, Avwiri et al., 2012 and Ononugbo et al., 2017).

The radioactivity content $\left(A_{c}\right)$ in $\mathrm{Bq} \mathrm{kg}^{-1}$ of the radionuclides were computed after decay correction was made using the expression (Adamu et al., 2013).

$$
A_{c}=\frac{N_{p}}{\varepsilon_{f f} \times M_{s} \times T_{c} \times \gamma_{p}} \quad B q k g^{-1}
$$

Where; $A_{c}$ is the sample activity concentration, $N_{p}$ is the net peak area of a peak at energy, $\varepsilon_{f}$ is the efficiency of the detector for a $\gamma$-energy of interest, $M_{s}$ is the sample mass, $T_{c}$ is the total counting time and $\gamma_{p}$ is the emission probability of radionuclide of interest. 


\section{2.4. Radiological Hazard Indices}

\subsubsection{Radium Equivalent Activity $\left(\mathrm{Ra}_{e q}\right)$}

4 The radium equivalent $\left(\mathrm{Ra}_{\mathrm{eq}}\right)$ activity is the measured number of activities of the natural

5

6

7

8

9 radionuclides (Radium, Thorium, Potassium) and is established on the proven fact that $1 \mathrm{~Bq}$ $\mathrm{kg}^{-1}$ of ${ }^{226} \mathrm{Ra}, 0.7 \mathrm{~Bq} \mathrm{~kg}^{-1}$ of ${ }^{232} \mathrm{Th}$, and $13 \mathrm{~Bq} \mathrm{~kg}^{-1}$ of ${ }^{40} \mathrm{~K}$ generate equal radiation dose rates (Osimobi et al., 2018). Radium equivalent $\left(\mathrm{Ra}_{\mathrm{eq}}\right)$ equates the specific activity levels of the sample contained in the three natural radioactivity $\left({ }^{40} \mathrm{~K},{ }^{226} \mathrm{Ra}\right.$ and $\left.{ }^{232} \mathrm{Th}\right)$ by a sole amount and account for the radiological risk (Agbalagba et al., 2012). The index is very useful in regulating safe allowable standards and is estimated using the expression (Kavitha et al., 2016):

$$
R a_{e q}=C_{R a}+1.43 C_{T h}+0.077 C_{k}
$$

where $R a_{e q}\left(\mathrm{~Bq} \mathrm{~kg}^{-1}\right)$ is the radium equivalent, $C_{R a}, C_{T h}$ and $C_{k}$ are the activity levels $\left(\mathrm{Bq} \mathrm{kg}^{-}\right.$ $\left.{ }^{1}\right)$ of ${ }^{226} \mathrm{Ra},{ }^{232} \mathrm{Th}$, and ${ }^{40} \mathrm{~K}$ respectively. Every material or environment whose $R a_{e q}$ values exceed $370 \mathrm{~Bq} \mathrm{~kg}^{-1}$ is strongly advised to be avoided (Wang et al., 2017).

\subsubsection{Absorbed Dose Rate $\left(D_{R}\right)$}

The outdoor $\left(D_{R}\right)$ is the gamma emission in air which represents an even dispersal of ${ }^{40} \mathrm{~K},{ }^{226} \mathrm{Ra}$ and ${ }^{232} \mathrm{Th}$. The outdoor $\left(\mathrm{D}_{\mathrm{R}}\right)$ value is computed using the guidelines given by UNSCEAR and is expressed as (Ashraf et al., 2010; UNSCEAR 2010):

$$
D_{R}=0.462 C_{R a}+0.621 C_{T h}+0.0417 C_{K}
$$

where $D_{R}\left(\eta G y h^{-1}\right)$ is the outdoor dose rate, $C_{k}, C_{R a}, C_{T h}$, are the activity content levels in $\left(\mathrm{Bq} \mathrm{kg}^{-1}\right.$ ) for ${ }^{40} \mathrm{~K},{ }^{226} \mathrm{Ra}$ and ${ }^{232} \mathrm{Th}$, respectively.

UNSCEAR (2010) reported that the global permissible limit value of absorbed dose for the public should be $59 \mathrm{nGy} \mathrm{h}^{-1}$.

\subsubsection{Annual Gonadal Equivalent Dose (AGED)}

Protecting the vital organs outer layers is of key importance to the radiation community (UNSCEAR 2000; 2010). The AGED is estimated using equation 4:

$$
A G E D=3.09 C_{R a}+4.18 C_{T h}+0.314 C_{k}
$$

where AGED is the Annual Gonadal Equivalent Dose $\left(\mathrm{mSv} \mathrm{y}^{-1}\right)$, and $C_{R a}, C_{T h}$, and $C_{k}\left(\mathrm{~Bq} \mathrm{~kg}^{-}\right.$ ${ }^{1}$ ) are the radioactivity levels of ${ }^{226} \mathrm{Ra},{ }^{232} \mathrm{Th}$, and ${ }^{40} \mathrm{~K}$, respectively. 
2 The hazard index $\left(\boldsymbol{H}_{\boldsymbol{e x}}\right)$ was a derivative of the Raeq calculation with the assumption that the maximum permissible value agrees with the $370 \mathrm{~Bq} \mathrm{~kg}^{-1}$ upper limit of $\mathrm{Ra}_{\mathrm{eq}}$ value, with its equivalent radiation dose value limited to $1.0 \mathrm{mSv}^{-1}$. The $\left(\boldsymbol{H}_{\boldsymbol{e x}}\right)$ index is computed applying

5 the expression (Wang et al., 2016):

$6 \quad H_{e x}=C_{R a} / 370+C_{T h} / 259+C_{k} / 4810$

7

8

9

where $H_{e x}$ is the external hazard index $\left(\mathrm{Bq} \mathrm{kg}^{-1}\right)$, and $C_{k}, C_{R a}$ and $C_{T h}$

are the radioactivity levels in $\left(\mathrm{Bq} \mathrm{kg}^{-1}\right)$ for ${ }^{40} \mathrm{~K},{ }^{226} \mathrm{R}$ and ${ }^{232} \mathrm{Th}$ respectively.

\subsubsection{Internal Hazard Index $\left(\boldsymbol{H}_{\text {in }}\right)$}

The internal index $\left(H_{\text {in }}\right)$ is estimated as (Kavitha et al., 2016):

$H_{\text {in }}=C_{R a} / 185+C_{T h} / 259+C_{k} / 4810$

where $H_{\text {in }}$ is the internal hazard index $\left(\mathrm{Bq} \mathrm{kg}^{-1}\right)$, and $C_{k}, C_{R a}, C_{T h}$ are radioactivity levels in $\left(\mathrm{Bq} \mathrm{kg}^{-1}\right)$ for ${ }^{40} \mathrm{~K},{ }^{226} \mathrm{R}$ and ${ }^{232} \mathrm{Th}$, respectively. $H_{\text {in }} \leq 1$ implies negligible radiation risk. Internal exposure to radon is very hazardous and can result to lung diseases like asthma and lung cancer.

\subsubsection{Representative Gamma $\left(I_{y r}\right)$}

The representative gamma was formulated to estimate the $\gamma$-radiation risk linked to a specific natural radionuclide samples being investigated. It is an analytical tool for categorizing samples that might cause radiological implications if deployed for construction (Agbalagba et al 2012). Values of $I_{\gamma} \leq 1$ correspond to $1.0 \mathrm{mSv}$, while $I_{\gamma} \leq 0.5$ is within an annual effective dose of $0.3 \mathrm{mSv}$ (Wang et al 2017).

The $I_{\gamma}$ is expressed as (Ashraf et al., 2010):

$$
I_{\gamma}=C_{R a} / 150+C_{T h} / 100+C_{K} / 1500
$$

where $I_{\gamma}$ is the representative gamma index $\left(\mathrm{Bq} \mathrm{kg}^{-1}\right)$, and $C_{k}, C_{R a}, C_{T h}$ are the radioactivity content values $\left(\mathrm{Bq} \mathrm{kg}^{-1}\right)$ for ${ }^{226} \mathrm{R},{ }^{232} \mathrm{Th}$ and ${ }^{40} \mathrm{~K}$ respectively.

\subsubsection{Annual Effective Dose Equivalent (AEDE) Outdoor}

The AEDE keeps control on the effects of radiation on reproductive organs. This hazard index received outdoor by an individual is given as (Avwiri et al., 2012; Ononugbo et al., 2017):

$A E D E($ Outdoor $)=D R \times 8760 \times 0.7 \times 0.2 \times 10^{-3}$ 
Where;

$A E D E$ (Outdoor) is given in $\mu S v y^{-1}, D R$ in $n G y h^{-1}, 0.7$ is the dose conversion factor given in $S v G y^{-1}, 8760 \mathrm{~h}$ is the in a year and $0.2 \times 10^{-3}$ is the occupancy factor for outdoor.

\subsubsection{Excess Lifetime Cancer Risk (ELCR)}

Excess lifetime cancer risk estimates the likelihood of contracting cancer over a lifetime at specific exposure rate. It is the estimated number of extra cancers probable in each population of persons on exposure to a radiation at a specific dose.

The ELCR is computed using the expression (Taskin et al., 2009):

$E L C R=A E D E \times D L \times R F$

where ELCR has no units, AEDE is as defined in equation 8, the average Duration of Life (70 years) is the DL, while RF is known to as the Risk Factor, i.e., lethal cancer risk per Sievert $\left(\mathrm{Sv}^{-1}\right)$. ICRP recommend RF as 0.05 for stochastic effects for the public (Taskin et al., 2009).

In order to further understand our results, statistical analyses were performed using the SPSS software tool for mathematical/statistical data analysis. These include; Skewness, Kurtosis, mean, median, mode, standard deviation, minimum and maximum values.

\subsection{Total Effective Dose}

The total effective dose parameters depicting the occupational risk to oil and gas workers and the public' were estimated employing relevant conversion coefficients available in the literature (Table 3) using the equations (Kola et al., 2016):

External exposure $\left(\mathrm{D}_{\mathrm{ext}}\right)$ to gamma radiation from mine site and the exposed tailings, is calculated using the equation:

$$
D_{\text {ext }}=\sum A_{i} C_{\text {ext }} T_{e}
$$

Internal exposure $\left(D_{\text {inh }}\right)$ from inhalation of solid mineral dust and contaminated air, is estimated using the expression

$$
D_{i n h}=\sum A_{i} C_{i n h} \eta_{i n h} D_{f} T_{e}
$$

Internal exposure $\left(D_{\text {ing }}\right)$ from any accidental ingestion of solid minerals, is estimated using the equation:

$$
D_{\text {ing }} \sum A_{i} C_{\text {ing }} \eta_{\text {ing }} T_{e}
$$

where $\mathrm{A}_{\mathrm{i}}$ is the specific activity of nuclide $i$ in $\mathrm{Bq} \mathrm{kg}^{-1}, \mathrm{C}_{\text {ext }}$, is the effective dose coefficient for the nuclide in the contaminated surface measured in $\mathrm{Sv} \mathrm{h} / \mathrm{Bq} \mathrm{g}^{-1}, \mathrm{C}_{\text {inh }}$, is the dose coefficient for inhalation of the nuclide measured in $\mathrm{Sv} \mathrm{Bq}^{-1}, \eta_{\mathrm{inh}}$ is the breathing rate measured in $\mathrm{m}^{3} \mathrm{~h}^{-1}$, and $\mathrm{D}_{\mathrm{f}}$ is the dust loading factor, $\mathrm{C}_{\mathrm{ing}}$, is the dose coefficient for ingestion of the 
1 nuclide measured in $\mathrm{Sv} \mathrm{Bq}{ }^{-1}$; $\eta_{\text {ing }}$ is the ingestion rate for adults, measured in $\mathrm{kgh}^{-1}$ and $\mathrm{T}_{\mathrm{e}}$ is the exposure duration in years (ICRP, 1991, 1996).

\subsection{Results and Discussion}

\subsection{Results of Radioactivity Analysis}

The results of the soil $\gamma$-ray spectroscopy analysis in the ten solid mineral mine sites of the five eastern states of Nigeria are presented in Tables 1 . Table 2 presents the summary of the analyzed radionuclides and the radiation risk indices while Table 3 present the computed occupational risk estimation to workers in the solid mineral mine sites

\subsection{Discussion of Results}

\subsubsection{Specific Activity Concentration}

The specific radioactivity levels obtained for the three natural radionuclides ${ }^{40} \mathrm{~K},{ }^{226} \mathrm{Ra}$ and ${ }^{232} \mathrm{Th}$ in the investigated soil samples collected within solid mineral mine sites are shown in Table 1 . The analyzed data obtained for the Iron-stone mine site soil activity concentration in Ebonyi State, shows activity value range of 32.45- $80.58 \mathrm{~Bq} \mathrm{~kg}^{-1}, 7.29-30.66 \mathrm{~Bq} \mathrm{~kg}^{-1}$ and 25.88-67.61 $\mathrm{Bq} \mathrm{kg}{ }^{-1}$ for ${ }^{40} \mathrm{~K},{ }^{226} \mathrm{Ra}$ and ${ }^{232} \mathrm{Th}$ respectively. Their mean values are higher than the control values by $47 \%, 5 \%$ and $46 \%$ respectively, while the mean ${ }^{232} \mathrm{Th}$ activity concentration of $77.28 \mathrm{~Bq} \mathrm{~kg}^{-1}$ obtained is above the ICRP, IAEA and UNSEAR, recommended permissible limit of $30 \mathrm{~Bq} \mathrm{~kg}^{-1}$ for the public. This may be attributed to the parent rock material from which iron- stone was formed (UNSEAR 2010; IAEA, 2011). The activity concentration range for the kaolin mine sites soil samples in Imo State are 18.19-40.72 $\mathrm{Bq} \mathrm{kg}^{-1}, 54.33-91.64$ $\mathrm{Bq} \mathrm{kg}^{-1}$ and 37.46-142.42 $\mathrm{Bq} \mathrm{kg}{ }^{-1}$, for ${ }^{226} \mathrm{Ra}^{232}{ }^{23 h}$ and ${ }^{40} \mathrm{~K}$, respectively, while their mean percentage elevation over the control values are $45 \%, 37 \%$ and $62 \%$ respectively. This elevation over the values obtained from the control sample can be attributed to the presence of these solid minerals within and around these sampled soils. At the silica mine site in Abia State, the range of activity concentration of the soil samples obtained are $127.08-289.79 \mathrm{~Bq} \mathrm{~kg}^{-}$ ${ }^{1}, 36.61-71.01 \mathrm{~Bq} \mathrm{~kg}{ }^{-1}$ and $72.04-112.45 \mathrm{~Bq} \mathrm{~kg}^{-1}$ for ${ }^{40} \mathrm{~K},{ }^{226} \mathrm{Ra}^{2}$ and ${ }^{232} \mathrm{Th}$ respectively and the degree of their mean values elevation over the control value are $54 \%, 48 \%$ and $77 \%$ respectively, with the mean activity concentration values of ${ }^{226} \mathrm{Ra}\left(52.64 \mathrm{~Bq} \mathrm{~kg}^{-1}\right)$ and ${ }^{232} \mathrm{Th}$ (97.68 $\mathrm{Bq} \mathrm{kg}^{-1}$ ) exceeding their ICRP maximum permissible limits for the public (ICRP, 1996). These high values may be attributed to the influence of these radionuclides presents in solid minerals that are within the sampled soil environment. The percentage elevation of ${ }^{40} \mathrm{~K},{ }^{226} \mathrm{Ra}$ 
1 and ${ }^{232}$ Th activity concentrations in the soil samples of the bitumen mine site in Enugu State over the control sample are $29 \%, 41 \%$ and $62 \%$ respectively. The obtained activity concentrations in the soil samples from these mining sites compared favourably and agreed with the value reported from river sand sediment from across Enugu east in Enugu state (Ugbede, 2020). The ${ }^{232} \mathrm{Th}\left(68.79 \mathrm{~Bq} \mathrm{~kg}^{-1}\right)$ mean value was found to be well above the ICRP recommended permissible limits. Similarly, the percentage increase of ${ }^{40} \mathrm{~K},{ }^{226} \mathrm{Ra}$ and ${ }^{232} \mathrm{Th}$ radioactivity levels in the sampled soil for the coal mine site at Enugu state over the control sample are $43 \%, 47 \%$ and $66 \%$ respectively, with ${ }^{232}$ Th activity concentration grossly exceeded the global permissible limit for the public. This high value of ${ }^{232} \mathrm{Th}$ in the soil samples can be attributed to the high content of ${ }^{232}$ Th in coal mineral (Faanu et al., 2011; Innocent et al., 2013; Wang et al., 2017).

The radioactivity content range in the sampled soil at the clay mine sites in Imo State are 34.84275.58 $\mathrm{Bq} \mathrm{kg}^{-1}, 17.55-46.40 \mathrm{~Bq} \mathrm{~kg}{ }^{-1}$ and $36.25-84.87 \mathrm{~Bq} \mathrm{~kg}^{-1}$ in ${ }^{40} \mathrm{~K},{ }^{226} \mathrm{Ra}^{2}$ and ${ }^{232} \mathrm{Th}$ respectively. These range of values agrees with the reported natural activity concentration value in soil samples from Slovenia (Kovács et al., 2013). Their mean activity concentration percentage elevation over the control values is $51 \%, 50 \%$ and $47 \%$ respectively with ${ }^{232} \mathrm{Th}$ (58.91 $\mathrm{Bq} \mathrm{kg}^{-1}$ ) mean activity concentration still exceeding the global permissible limit for the public. The percentage elevation of ${ }^{40} \mathrm{~K},{ }^{226} \mathrm{Ra}$ and ${ }^{232} \mathrm{Th}$ activity levels in the sampled soil of the gypsum mine site at Enugu State over the control sample are 61\%, 63\% and 63\% respectively. The ${ }^{226} \mathrm{Ra}\left(49.46 \mathrm{~Bq} \mathrm{~kg}^{-1}\right)$, and ${ }^{232} \mathrm{Th}\left(67.25 \mathrm{~Bq} \mathrm{~kg}^{-1}\right)$ mean activity levels are above the global permissible limit $35 \mathrm{~Bq} \mathrm{~kg}^{-1}$ for ${ }^{226} \mathrm{Ra}$ and $30 \mathrm{~Bq} \mathrm{~kg}{ }^{-1}$ for ${ }^{232} \mathrm{Th}_{\text {for }}$ the public. At the coal mine site in Abia State, the activity concentration range of the sampled soil obtained are 25.67-174.22 $\mathrm{Bq} \mathrm{kg}^{-1}, 15.38-27.12 \mathrm{~Bq} \mathrm{~kg}^{-1}$, and 37.99-64.36 $\mathrm{Bq} \mathrm{kg}^{-1}$ for ${ }^{40} \mathrm{~K}^{2}{ }^{226} \mathrm{Ra}$ and ${ }^{232} \mathrm{Th}$ respectively. The percentage mean radioactivity levels elevation over the control value are $55 \%, 28 \%$ and $54 \%$ respectively, with mean ${ }^{232} \mathrm{Th}\left(55.31 \mathrm{~Bq} \mathrm{~kg}^{-1}\right)$ value observed to be above UNSCEAR recommended permissible limits for the general public (UNSCEAR, 2000). The activity concentration range of sampled soil at the limestone mine site in Ebonyi State as obtained are 23.73-313.74 $\mathrm{Bq} \mathrm{kg}^{-1}, 18.73-48.26 \mathrm{~Bq} \mathrm{~kg}^{-1}$ and $29.70-70.41 \mathrm{~Bq} \mathrm{~kg}^{-1}$, for ${ }^{40} \mathrm{~K},{ }^{226} \mathrm{Ra}$ and ${ }^{232} \mathrm{Th}$ respectively. Their mean percentage elevation over the control values is $62 \%, 60 \%$ and $64 \%$ respectively with ${ }^{232} \mathrm{Th}\left(48.78 \mathrm{~Bq} \mathrm{~kg}^{-1}\right)$ mean activity concentration agreeing with the value reported at Ezillo paddy rice field in Ebonyi State, but also exceeding the global permissible limit for the general public (Ugbene and Osahon, 2021). Similarly, the activity concentrations range for sampled soil at the glass stone mine site in Anambra State as measured 
1 are 21.00-70.10 Bq kg-1, 14.19-28.90 Bq kg-1 and 74.18-588.93 $\mathrm{Bq} \mathrm{kg}^{-1}$ for ${ }^{40} \mathrm{~K},{ }^{226} \mathrm{Ra}^{-1}{ }^{232} \mathrm{Th}^{-1}$ respectively. Their mean percentage rise of ${ }^{40} \mathrm{~K},{ }^{226} \mathrm{Ra}$ and ${ }^{232} \mathrm{Th}$ activity concentrations in the soil samples over the control sample are $39 \%, 58 \%$ and $82 \%$ respectively, with ${ }^{232} \mathrm{Th}(189.11$ $\mathrm{Bq} \mathrm{kg}^{-1}$ ) activity concentration grossly exceeded the public permissible limit.

The soil specific activity levels obtained in the entire surroundings of the mining sites for the different solid mineral clearly indicate that ${ }^{232} \mathrm{Th}$ radioactivity concentration is higher and exceed the three naturally occurring radionuclides examined permissible limits for the public. This is an indication that most of the solid minerals are laced with radioactivity with thorium activity most prominent, which may be attributed to the geological formation of the subsurface rocks of the studied area and the weathering processes that takes place. It was observed that the mean activity of ${ }^{226} \mathrm{Ra}$ and ${ }^{40} \mathrm{~K}$ reported in this study-areas are above many reported values in literatures in similar environment within Nigeria, West Africa and other parts of the globe (Faanu et al., 2011; González-Fernández et al., 2012; Innocent et al., 2013; Wang et al., 2017). Moreover, the ${ }^{226} \mathrm{Ra}$ value obtained in this study is well within reported values in literatures in similar solid mineral mining environments in Nigeria and in other parts of the world (Amrani and Tahtat, 2001; El Afifi et al., 2006; Kam and Bozkurt, 2007; Al-Hamarneh and Awadallah, 2009; Ademola and Obed, 2012; Avwiri et al., 2013; Kovács et al., 2013; Ademola et al., 2014; Hannan et al., 2015).

\subsubsection{Radiological Hazard Parameter Statistical Analysis}

Table 2 shows the summary of the result of the statistically analyzed specific activity levels and radiation hazard/ risk indices. The eight radiation risk parameters were computed using reported standard and internationally established equations in literatures (Ashraf et al., 2010; UNSCEAR, 2010; Avwiri, et al., 2012; Gang, et al., 2012; Sivakumar, et al., 2014; Wang, et $a l ., 2016)$. From the result, the estimated Radium Equivalent $\left(R a_{e q}\right)$ varied from $87.51 \mathrm{~Bq} \mathrm{~kg}^{-}$ ${ }^{1}$ to $300.13 \mathrm{~Bq} \mathrm{~kg}^{-1}$ with a mean and mode values of $150.72 \mathrm{~Bq} \mathrm{~kg}^{-1}$, and $87.51 \mathrm{~Bq} \mathrm{~kg}^{-1}$ respectively with a standard deviation of $61.25 \mathrm{~Bq} \mathrm{~kg}^{-1}$. This $R a_{e q}$ result obtained is above reported value obtained in s solid mineral mine site in south-western Nigeria and sampled soil valued obtained in some cities and towns in Nigeria (Agbalagba, et al., 2012; Avwiri, et al., 2012; Innocent et al., 2013; Ademola et al., 2014; Aliyu et al., 2015; Ononugbo et al., 2017; Ugbede, 2020; Ugbede and Osahon, 2021). The Absorbed dose rate (D) has a minimum value of $38.96 \eta G y h^{-1}$ and a maximum measured value of $133.00 \eta G y h^{-1}$ with $68.40 \eta G y h^{-1}$ be the mean. The mean absorbed dose value recorded exceeded the UNSCEAR, (2010) 
1 recommended worldwide ambient value of $59 \eta G y h^{-1}$. The outdoor Annual Effective Dose 2 Equivalent (AEDE) has its values varied from $48.26 \mu \mathrm{Svy}^{-1}$ to $160.78 \mu \mathrm{Svy}^{-1}$ with the mean and mode values of $83.65 \mu \mathrm{Svy}^{-1}$ and $48.26 \mu \mathrm{Svy}^{-1}$ respectively across the study-area and a standard deviation value of $32.66 \mu \mathrm{Svy}^{-1}$. The estimated average value of the outdoor Annual Effective Dose Equivalent of $83.65 \mu \mathrm{Svy}^{-1}$ correspond to the reported values obtained in measured soil samples in Bethlehem Province of Palestine and soil from open landfills site in Rivers State Nigeria, but it is higher the worldwide annual effective dose equivalent value of $70 \mu \mathrm{Svy}^{-1}$ for outdoor (Agbalagba et al., 2012; Mohammad et al., 2014; Ononugbo et al., 2017; Vukasinovic et al., 2017; Ugbede, 2020).

The estimated value of the Annual gonadal equivalent dose (AGED) varied from $263.62 \mu \mathrm{Svy}^{-}$ ${ }^{1}$ to $879.51 \mu \mathrm{Svy}^{-1}$ with a mean value of $454.70 \mu \mathrm{Svy}^{-1}$. The estimated value recorded is above the ambient level recommended world permissible value of $300 \mu \mathrm{Svy}^{-1}$ and values obtained in reported research of wasteland soil in Namibia, but they are below the values reported in southern dump site sampled soil and Northern soil samples from solid mineral mining environment Nigeria as reported in literatures (UNSCEAR, 2010; Aliyu et al., 2015; Ononugbo et al., 2017; Onjefu et al., 2021). The accumulative dose rate at the present exposure rate over a twenty years' time may impair the reproductive organs (ovaries and testis) of those working and living around these mine sites if not properly shielded.

The mean results of the estimated health hazard indices indicates that External hazard index $\left(H_{e x}\right)$ has a mean value of 0.41 , while the estimated Internal hazard index $\left(H_{\text {in }}\right)$ value is 0.50 and the Representative gamma index $\left(I_{\gamma}\right)$ had a value of 1.06. The results are comparable favourably with the values reported in Wasteland soil of Okakarara in Namibia, the shore sediment of North dune beach in Namibia and the values reported in soil and sediment of AlNigella in Egypt (Onjefu et al., 2017; Ahmed et al., 2020; Onjefu et al., 2021). The mean hazard indices values obtained for $H_{e x}$ and $H_{\text {in }}$ are less than the 1.0 (critical value), the general public recommended permissible limit, however, Representative gamma index $\left(I_{\gamma}\right)$ value of 1.06 obtained was slightly above the UNSEAR recommended value for the general public (UNSCCEAR, 2010). These obtained estimated values of the Excess Life Cancer Risk (ELCR) result ranged from $165.45 \times 10^{-6}$ to $559.31 \times 10^{-6}$ with a regular value of $289.14 \times 10^{-6}$. This mean ELCR value of $289.14 \times 10^{-6}$ obtained is approximately the recommended ambient public permissible limit of $0.29 \times 10^{-3}$ (UNSCEAR, 2000). This implies that the likelihood of radiation induced health risks among residence and workers in the environs of these mine sites is probable, especially for prolong and continuous radiation exposures from these studied 
minerals sites. The statistical analysis of the results of radionuclides and the radiological risk indices are indicated in figure 3, while figure 4 shows the sequential chart distribution of the three natural radionuclides investigated with the radiological risk parameters examined. It was observed from figure 3 that the histogram showing the spatial dispersion of specific activities of the three natural radionuclides $\left({ }^{40} \mathrm{~K},{ }^{226} \mathrm{Ra}\right.$ and $\left.{ }^{232} \mathrm{Th}\right)$ in the analyzed soil samples from the investigated sites, were asymmetrical distribution with the skewness of $0.19,0.61,2.53$ respectively. The median values for ${ }^{40} \mathrm{~K},{ }^{226} \mathrm{Ra}$ and ${ }^{232} \mathrm{Th}$ were $99.80,32.23$ and $68.34 \mathrm{~Bq} \mathrm{~kg}^{-1}$ respectively, thus data obtained in this study were accepted as reliable for use in the determination of the radiological risk (Kessaratikoon et at., 2019). From figure 4, the two rigs in the sequence chart are an indicative of the areas of high aggregation of the activity concentrations and areas of strong correlation of activities concentration with radiological risk parameters.

\subsubsection{Occupational Risk Estimate}

This model account for the occupational hazard associated with work environment, which in this study is the solid mineral mining sites. As a result of constant working at the sites and in most cases not wearing the appropriate Personnel Protective Equipment (PPE), workers are often exposed to radionuclide. The three major paths for this exposure are according to Kolo et al. (2016):

The total of these three different paths of exposure gives the total effective dose which is the concerned parameter. To be within the safe ICRP limit, the Total Effective Dose from these three pathways must not be more than $1.0 \mathrm{~m} \mathrm{Sy}^{-1}$ for the public (ICRP, 1991).

The result presented in Table 3 of the Occupational Risk Estimate indicates that the external exposure to gamma radiation $\left(\mathrm{D}_{\mathrm{ext}}\right)$ has the highest Occupational risk ranging from $0.51 \mathrm{mSv} \mathrm{y}^{-}$ ${ }^{1}$ to $1.3 \mathrm{mSv} \mathrm{y}^{-1}$, followed by Internal exposure from inhalation of radiation from solid mineral dust and contaminated air $\left(\mathrm{D}_{\mathrm{inh}}\right)$ ranging from $0.01 \mathrm{mSv}^{-1}$ to $0.99 \mathrm{mSv}^{-1}$ and the least is Internal exposure from any accidental ingestion of radiation from solid minerals $\left(\mathrm{D}_{\text {ing }}\right)$ ranging from $0.08 \mathrm{mSv}^{-1}$ to $0.24 \mathrm{mSv}^{-1}$. The reason for this result distribution is obvious as one in a mining site would be exposed externally on the skin and inhalation before even having to experience accidental ingestion. This result indicates that the external organs like the eye and skin of the people working at these mining sites may be at risk of eye and skin radiation related infections. However, the overall results suggests that the effect put together is within control limit as the whole organs of the body fights together to wear the would-be effect from one pathway. 


\section{Conclusion}

2 The evaluation of natural radioactivity levels of sampled soil from some selected solid minerals

3 mining sites and soil from non-mineral mining areas (control) in the Eastern region of Nigeria

4 has been investigated using gamma spectroscopy analysis. The measured soil activities of ${ }^{40} \mathrm{~K}$, ${ }^{226} \mathrm{Ra}$ and ${ }^{232} \mathrm{Th}$ were deploy to compute the percentage gamma radiation elevation over the control sample and the risk parameters. Radioactivity analysis of the sampled soil shows that some radionuclides values measured exceeded their standard limits. The overall average percentage rise in ${ }^{40} \mathrm{~K},{ }^{226} \mathrm{Ra}$ and ${ }^{232} \mathrm{Th}$ value in the mine sites soil samples over the control soil samples are $48.6 \%, 43.7 \%$ and $62.3 \%$ respectively, with thorium having the highest percentage rise. This affirmed previous research report of ${ }^{232} \mathrm{Th}$ be the major contributor of the dose that can be received from the terrestrial environment. The occupational risk estimation results indicate that the external organs of the people working and living around these mining sites are at risk which may lead to eye and skin radiation related infections. The exceeding of global recommended permissible and ambient limits of certain radiation hazard indices estimated compared to previously reported values from similar mineral mining environment is an indication of a radiologically contaminated environment, which is attributable to the solid minerals mining and processing in the studied areas. The researcher therefore recommends that proper kitting of workers and discouragement of people residing around these mining sites to reduce the radiation impact on people and the environment.

\section{Acknowledgement}

The authors wish to appreciate the assistance of the Federal Ministry of Solid Minerals for providing us the needed information, materials and access for the success of this investigation

\section{Ethical Approval}

This paper abides by all ethical standard of the journal and contain no ethical issues whatsoever.

\section{Consent to Participate}

All authors consent was sorted and agreed before the research work commenced. All authors also consent to participate in the writing of this article and the submission of the final paper to this journal.

\section{Consent to Publish}

This is to certify that all authors consents were sorted and approval gotten to publish this paper in this Journal. We the authors declare that there is no conflict of interest among us in this research work.

\section{Authors' contributions}


1 The research work was conceived by Dr. Agbalagba E.O and redesign for wider readability by

2 Prof. Stephen O. Egarievwe, while Dr. Mohammed S. Chaanda did the geological identification and characterization of sites and solid minerals in each site. All the three authors contributed mutually from the development and data analysis in this research work. Dr. Agbalagba E.O. did the writing which other authors vetted and agreed before sending for consideration in this Journal.

\section{Funding}

We the authors state that there is no funding of any kind from individual, cooperate bodies or government agencies in this research work.

\section{Availability of Data and Material}

The datasets generated and/or analyzed during the current study are not publicly available, but will be made available from the corresponding author on reasonable request

\section{Competing Interests}

Not applicable

\section{References}

Abodunrin, O., Ademo A., and Akinbo, T. (2017). Terrestrial gamma radiation exposure measurement and risk estimates in the environments of major industries in OTA, Nigeria. Environmental Quality 21, 11-17.

Adamu, R., Zakari Y. I., Ahmed A. Y., Abubakar S., and Vatsa, A. M. (2013). Analysis of activity concentrations due to natural radionuclides in the fish of Kainji Lake. Advances in Applied Science Research 4(4), 283-287.

Ademola, A. K, Adekunle, K. B., and Adeyeni, C. A. (2014). Determination of natural radioactivity and hazard in soil samples in and around gold mining area in Itagunmodi, south-western, Nigeria. Journal of Ra $d i$ a $t$ i o $n$ Research and App li e d S c i e n c e s 7,249-255.

Ademola, A. K., and Obed, R. I. (2012) Gamma radioactivity levels and their corresponding external exposure of soil samples from Tantalite mining areas in Oke-Ogun, South-Western Nigeria. Radioprotection Journal, (47), 243-252.

Ademola, J. A. and Onyema, U. C. (2014). Assessment of natural radionuclides in fly ash produced at Orji River Thermal Power Station, Nigeria and the associated radiological impact. Natural Science, 6, 752-759.

Agbalagba E.O., Avwiri G. O., and Chad-Umoreh, Y. E. (2012). $\gamma$-spectroscopy measurement of natural radioactivity and assessment of radiation hazard indices in soil samples from oil fields environment of Delta State, Nigeria. Journal of Environmental Radioactivity 109, 64-70.

Agbalagba, E. O., and Onoja, R. A. (2011). Evaluation of natural radioactivity in soil, sediment and water samples of Niger delta (Biseni) flood plain lakes, Nigeria. J. Environ. Rad. 102: 667-671. 
Ahmed, N.S., Ahmed, O. Sayed, A.E. and Tawfic, A.F., (2020). Analysis of natural radionuclides and ${ }^{137} \mathrm{Cs}$ and HPGe spectrometer and radiological hazards assessment for Al-Nigella site, Egypt. International Journal of Environmental Analytical Chemistry. DOI: 10.1080/03067319.2020.1724985

Aigbedion, I., and Iyayi, S. E. (2007). Radiation studies. International Journal of Physical Sciences 2; 33-38.

Al-Hamarneh I. F., and Awadallah, M. I. (2009). Soil radioactivity levels and radiation hazard assessment in the highlands of northern Jordan. Radiation Measurement 44 (1), 102110.

Aliyu, A. S., Ibrahim. U, Akpa, C. T., Garba, N. N., and Ramli, A. T. (2015). Health and ecological hazards due to natural radioactivity in soil from mining areas of Nasarawa State, Nigeria. Isotopes Environ Health St udy 51(3), 448-468.

Amrani, D., and Tahtat, M. (2001). Natural radioactivity in Algeria building materials. Jounal of Applied Radiation and Isotopes 54, 687-689, 2001.

Anagnostakis, M.J., Hinis, E.P., Simopoulos, S.E. and Angelopoulos, M. G. (1996). Natural radioactivity mapping of Greek surface soil. Environ. Int. 22, 3-8.

Arogunjo, M.A., Farai, I.P. and Fuwape, I.A. (2004). Impact of oil and gas industry to the natural radioactivity distribution in the delta region of Nigeria. Nig. J. Phys., 16, 131136.

Ashraf, E. M. K., Layia, H. A., Amany A. A., and Al-Omran, A. M. (2010). NORM in clay deposits. Proceedings of Third European IRPA Congress 2010 June 14- 18, Helsinki, Finland, Pg 1-9.

Avwiri, G. O, Enyinna, P. I., and Agbalagba, E. O. (2010). Occupational Radiation Levels in Solid Mineral Producing Areas of Abia State, Nigeria, Scientia Africana. 9 (1), 93 97.

Avwiri, G. O., Osimobi, J. C., and Agbalagba, E. O. (2012). Evaluation of Radiation Hazard Indices and Excess Lifetime Cancer Risk Due to Natural Radioactivity in soil profile of Udi and Ezeagu Local Government Area of Enugu State, Nigeria.

Avwiri G.O., Egieya J.F., and Chinyere P. O., 2013. Radiometric Survey of Aluu Landfill, In Rivers State, Nigeria. Advances in Physics Theories and Applications 22: 24-30.

Balogun, F. A., Mokobia, C. E., Fasasi, M. K., and Ogundare, F. O. (2003). Natural radioactivity associated with bituminous coal mining in Nigeriall. Nuclear Instruments and Methods in Physics Research A 505, 444-448.

Baratta, E. J. (1990). Radon, radium and uranium in drinking water. Lewis Publisher, Washington DC, 203-213.

Beretka, J., and Mathew P. J. (1985). Natural radioactivity of Australia Building materials industrial wastes and by-products. Health Phy. 48, 87-95. 
Dolchinkov, N. T., and Nichev, N. B. (2017). Radiation background of the atmosphere, soil and water in Bulgaria and its monitoring in the contemporary political conditions. Security \& Future, 1(1), 17-20.

Ekeocha, C. (2016). Uranium Mining and Milling in Nigeria. Nigerian geological survey agency. NGS annual bulletin Vol.31.

El Afifi, E. M., Hilal, M. A., Khalifa, S. M., and Aly, H. F. (2006). Evaluation of U, Th, K and emanated radon in some NORM and TENORM samples. Radiation Measurements, 41, 627633.

El-Bahi, S. M. (2004). Assessment of radioactivity and radon exhalation rate in Egyptian cement. Health Physics 86, 517-522.

El-Dine, N. W., EL-Shershaby, A., Ahmed F., and Abdel-Haleem, A. (2001). Measurement of radioactivity and radon exhalation rate in different kinds of marble and granites. Applied Radiation and Isotopes, 55 (6), 853-860.

Environmental Protection Agency (EPA) (1999). Cancer risk coefficients for environmental exposure to radionuclides. United State Environmental Protection Agency. Federal Guidance Report No. 13 (EPA, 402 R-99-001).

Ezeh, C.C. (2011). Geoelectrical studies for estimating aquifer hydraulic properties in Enugu State, Nigeria, International Journal of the Physical Sciences. 6(14), 3319-3329.

Ezeh, C.C., and Ugwu, G.Z. (2010). Geoelectrical sounding for estimating groundwater potential in Nsukka L.G.A. Enugu State, Nigeria. International Journal of the Physical Sciences. 5(5), 415-420.

Faanu, A., Darko, E. O., and Ephraim, J. H. (2011). Determination of natural radioactivity and hazard in soil and rock samples in a mining area in Ghana. W. Afr. Journal of Applied Ecology. 19, 77-92.

Gang, S., Diyun, C., Zeping, T., Zhiquang, Z., and Wenbiao, X. (2012). Natural radioactivity levels in topsoil from the Pearl River Delta zone, Guangdong, China. Journal Environmental Radioactivity 103, 48-53.

Gonzalez- Fernandez, D., Garrido-Perez, M.C., Cases-Ruiz, M., Barbero, L., and Nebot-Sanz, E. (2011). Radiological risk assesses of naturally occurring radioactivity materials in marine sediments and its application in industrial coastal areas. Bay of Algeciras. Environmental Earth Science 66,1175- 1181.

Guidicini, O. M., Paschoa, A. S., Saad, S., and Goldemberg, J. (1992). Radioactive risk associated with mining activities. Comparative risk assessment of different energy sources, 75.

Hannan, M., Wahid, K. and Nguyen, N. (2015). Assessment of natural and artificial radionuclides in Mission (Texas) surface soils. J. Radioanal. Nucl. Chem. 305(2), 573-582.

ICRP (International Commission on Radiological Protection) (1991). The 1990 Recommendations of the International Commission on Radiological Protection, Vol. 2123. Elsevier Health Sciences, USA.

ICRP (International Commission on Radiological Protection) (1996). Age - dependent doses to members of the public from intake of radionuclides. Part 5: Compilation of ingestion and inhalation coefficients ICR Publication 72, Oxford: Pergamon Press. 
Innocent, J.A, Onimisi, M. Y., and Jonah, S. A. (20113). Evaluation of Naturally Occurring Radionuclide Materials in Soil Samples Collected from Some Mining Sites in Zamfara State, Nigeria. British Journal of Applied Science \& Technology 3(4), 684-692. science-domain international,

Jibril, N., Farai, I. P., and Ogunlana, A. M. (1999). Radioactivity levels of some Nigeria Rock samples. Nigeria Journal of Physics 11, 22-25.

Kam, E., and Bozkurt, A. (2007). Environmental radioactivity measurements in Kastamonu region of northern Turkey. Applied Radiation and Isotopes 65(4), 440-4. DOI: 10.1016/j.apradiso.2006.11.005.

Kessaratikoon P., Choosiri N., Boonkrongcheep R. and Youngchuay U. (2019). Measuremnt of natural $\left({ }^{40} \mathrm{~K},{ }^{226} \mathrm{Ra}\right.$ and $\left.{ }^{232} \mathrm{Th}\right)$ and anthropogenic $\left({ }^{137} \mathrm{Cs}\right)$ gamma radiation and radiological hazard assessment in beach sand samples collected from Ao Phrao at Koh Samt in Rayong province (Thailand). IOP Conf. Series: Journal of Physics Conf. Series 1285. doi:10.1088/17426596/1285/1/012013.

Kolo, M. T., Khandaker, M. U., Amin Y. D., and Abdullah, W. H. (20116). Quantification and Radiological Risk Estimation Due to the Presence of Natural Radionuclides in Maiganga Coal. Nigeria.

Kovacs, T., Szeiler, G., Fabian, F., Kardos, R., Gregoric, A., and Vaupotic, J. (2013). Systematic survey of natural radioactivity of soil in Slovenia. Journal of Environmental Radioactivity 122, 70-78.

Mane, S., Mane, T. and A. (2014). Sharma, Environmental Natural Gamma Radiation Level and Activity of Uranium-238, Thorium-232 at Different Places Measured Using NaI (Tl) Scintillation Detector. International Journal of Science and Research (IJSR) 3(12), 297-302.

Mokobia, C. E., Adebiyi, F. M., Akpan I., Olise, F. S., and Tchokossa, P. (2006). Radioassay of prominent Nigerian fossil fuels using gamma and TXRF spectroscopy. Fuel, 85, 1811-1814.

Nigerian Vision 2020, Report of the Vision 2020 National Technical Working Group on Minerals and Metals Development (July 2009).

Obaje, N. G., Moumouni, A., Goki, N. G., and Chaanda, M. S. (2011). Stratigraphy, paleogeography and hydrocarbon resource potentials of the Bida Basin in NorthCentral Nigeria. Journal of Mining and Geology, 47(2), 97-114.

Omotehinse, A. O., and Ako, B. D. (2019). The environmental implications of the exploration and exploitation of solid minerals in Nigeria with a special focus on Tin in Jos and Coal in Enugu. Journal of Sustainable Mining 18(1), 18-24.

Onjefu, S.A., Kamunda, C. and Abah, J. (2021). Health risk of natural radioactivity in wasteland soil in Okakarara, Namibia. Arab J. Nucl. Sci. Appl. 54(2):143-150.

Onjefu, S.A., Kgabi, N.A., Taole, S.H., Grant, C. and Antonie, J., (2017). Assessment of natural radionuclide distribution in shore sediment samples collected from the North Dune Beach, Henties Bay, Namibia. J. Radiat. Res. Appl. Sci. 10: 301-306.

Ononugbo, C. P., Avwiri, G. O., and Agbalagba, E. O. (2017). Radioactivity pollution and excess lifetime cancer risk due to gamma exposure of soil and ground water around open landfills in Rivers State, Nigeria. Canadian Journal of Pure and Applied Sciences 11(1), 4121-4130. 
Orgun, Y., N. Altinsoy, S. Y. Sahin, Y., Gungor, A. H., Gultekin, G., Karaham and Karaak, Z. (2007). Natural and anthropogenic radionuclide in rocks and beach sands from Ezine region, Western Anatolia, Turkey. Applied Radiation and Isotopes 65, 739-747.

Osimobi, J.C., Avwiri, G.O., and Agbalagba E.O. (2018). Radiometric and radiogenic heat evaluation of natural radioactivity in soil around solid minerals mining environment in South-eastern Nigeria. Springer, Environmental Process 5(4),860-877.

Ragheb, M. (2007). Radiation hormesis. Department of nuclear, plasma, and radiological engineering, University of Illinois at Urbana-Champaign, Champaign, IL. Retrieved from https://netfiles.uiuc.edu/mragheb/www/NPRE\%20402\%20ME\%20405\%20Nuclear\%20P ower\%20Engineering/Radiation\%20Hormesis.pdf.

Richardson, M. D. (2005). Changing patterns and trends in systemic fungal infections. Journal of Antimicrobial Chemotherapy, 56(suppl_1), i5-i11.

Sadiq, A. A., and Agba, E. H. (2011). Background Radiation in Akwanga, Nigeria. Facta Universitatis; Series: Working and Living Environmental Protection. 8 (1), $7-11$.

Sam A. K., and Abbas, N. (2001). Assessment of radioactivity and the associated hazards in local and imported cement types used in Sudan. Radiation Protection Dosimetry 93, 275-277.

Sivakumar, S., Chandrasekaranb, A., Ravisankarc, R., Ravikumarc, S., Prince, M. J., Prakash, J., Vijayagopale, P., Vijayalakshmie I., and Jose, M. T. (2014). Measurement of natural radioactivity and evaluation of radiationhazards in coastal sediments of east coast of Tamilnadu using statistical approach. Journal of Taibah University for Science 8, 375384.

Taskin, H., Karavus, M., Ay, P., Topuzoghi, A., Hindiroglu, S., and Karaha, G. (2009). Radionuclide concentrations in soil and lifetime cancer risk due to the gamma radioactivity in Kirklareli. Turkey Journal of Environmental Radioactivity 100, 4953.

Tufail, M., Akhtar, N., Jaried, S., and Hamid, T. (2007). Natural radioactivity hazards of building bricks fabrication from soil of two districts of Pakistan, Journal of radiological protection $27,481-492$.

Turhan, S., and Gunduz, L. (2008). Determination of specific activity of ${ }^{226} \mathrm{Ra},{ }^{232} \mathrm{Th}$ and ${ }^{40} \mathrm{~K}$ for assessment of radiation hazards from Turkish pumice samples. Journal of Environmental Radioactivity 101, 54-62. dio: 10:1016/j.jenvrad.2007.08.002.

Ugbede, F. O., and Echeweozor, E. O. (2017). Estimation of Annual Effective Dose and Excess Lifetime Cancer Risk from Background Ionizing Radiation Levels Within and Around Quarry Site in Okpoto-Ezillo, Ebonyi State, Nigeria. Journal of Earth and $\begin{array}{llll}\text { Environmental } & \text { Sciences, } & \text { 123-129. }\end{array}$ https://iiste.org/Journals/index.php/JEES/article/view/40232

Ugbede, F. O., (2020). Distribution of 40K, 238U and 232Th and associated radiological in rivers sediments across Enugu East, Nigeria. Environ. Nanotechnol. Monit. Manage. 20, 100317 . 
Ugbede, F.O. and Osahon, O.D., (2021). Soil-to-plant transfer factors of 238U and 232Th in rice from Ezillo paddy fields, Ebonyi State, Nigeria. Journal of Environmental Radioactivity 233:106606,

UNSCEAR (2010). United National Scientific Committee on the Effects of Atomic Radiation. Sources and Effects of Ionizing Radiation: Report to the General Assembly, with scientific annexes vol 1 (United Nations, New York): 1-219.

UNSCEAR (United Nation Scientific Committee on the Effects of Atomic Radiation) (1988). Sources, effects and risks of ionizing radiation, Annex B, United Nations, New York.

UNSCEAR, (United Nation Scientific Committee on the Effects of Atomic Radiation) (2000). Sources and effect of Ionizing radiation. Report to the general assembly with scientific annexes. United Nations; New York.

UNSCEAR, (United Nation Scientific Committee on the Effects of Atomic Radiation) (2008). Report vol.1 to the General Assembly with scientific Annexes: United Nations Sales Publications, United Nations, New York.

Wang, J., Du, J., and Qiaquian, B. (2017). Natural radioactivity assessment of surface sediments in the Yangtze estuary. Marine Pollution Bulletin 114, 602-608.

Wang, Z., Du, Y., Baskaran, M., and Zhang, J. (2016). Mobile mud dynamics in the East China Sea elucidated using $210 \mathrm{~Pb}, 137 \mathrm{Cs}, 7 \mathrm{Be}$ and $234^{\mathrm{Th}}$ as tracers. J. Geophys. Res. Oceans $121(1)$, 224-239.

Wang, Z., He, J., Du, Y., Li, Z., Chen, Z., and Yang, C. (2011). Natural and artificial radionuclide measurements and radioactivity assessment of soil samples in eastern Sichuan province (China). Radiat. Prot. Dosim 150(4), 391-397.

Zarie, K. A., and Al Mugren, K. S. (2010). Measurement of natural radioactivity and assessment of radiation hazard in soil samples from Tayma area (KSA). Isotope and Rad. Res.42 (1), 1- 9.

Ziqiang, P., Zhenyum H., Yin Y., and Mingqiang, G. (1994). Natural background radiation and population dose in China. Radioprotection 29(1), 69-80. 
5

6

7

8

9

10

\section{List of Tables}

Table 1: Activities $\left(\mathrm{Bq} \mathrm{kg}{ }^{-1}\right)$ of ${ }^{40} \mathrm{~K},{ }^{226} \mathrm{Ra},{ }^{232} \mathrm{Th}$ from solid mineral mining soils in South-Eastern Nigeria

\begin{tabular}{|c|c|c|c|c|c|c|}
\hline $\mathbf{S} / \mathbf{N}$ & $\begin{array}{l}\text { geographical } \\
\text { location }\end{array}$ & $\begin{array}{c}\text { Mining } \\
\text { State }\end{array}$ & $\begin{array}{l}\text { Mineral } \\
\text { found }\end{array}$ & $\begin{array}{l}{ }^{40} \mathrm{~K}\left(\mathrm{~Bq} \mathrm{~kg}{ }^{-1}\right) \\
\text { Mean (Range) }\end{array}$ & $\begin{array}{l}{ }^{226} \text { Ra }\left(\mathrm{Bq} \mathrm{kg}^{-1}\right) \\
\text { Mean (Range) }\end{array}$ & $\begin{array}{l}{ }^{232} \text { Th }\left(\mathrm{Bq} \mathrm{kg}^{-1}\right) \\
\text { Mean (Range) }\end{array}$ \\
\hline 1 & $\begin{array}{l}\text { N06 }^{\circ} 22^{\prime} 45^{\prime \prime} \\
\text { E007을 } 27^{\prime} 52^{\prime \prime}\end{array}$ & Ebonyi & Ironstone & $54.26(32.45-80.58)$ & $20.45(7.29-30.66)$ & $48.18(25.88-67.61)$ \\
\hline 2 & $\begin{array}{l}\mathrm{N}^{\circ} 6^{\circ} 45^{\prime} 44^{\prime \prime} \\
\mathrm{E} 007^{\circ} 16^{\prime} 17^{\prime \prime}\end{array}$ & Imo & Kaoline & $81.65(37.46-142.42)$ & $31.83(18.19-40.72)$ & 71.08 (54.33-91.64) \\
\hline 3 & $\begin{array}{l}\mathrm{N}^{\circ} 6^{\circ} 28^{\prime} 08^{\prime \prime} \\
\mathrm{E} 007^{\circ} 27^{\prime} 03^{\prime \prime}\end{array}$ & Abia & Silica & 179.15 (127.08-289.79) & $52.64(36.61-71.01)$ & $97.68(72.04-112.45)$ \\
\hline 4 & $\begin{array}{l}\mathrm{N} 06^{\circ} 05^{\prime} 27^{\prime \prime} \\
\mathrm{E} 007^{\circ} 26^{\prime} 34^{\prime \prime}\end{array}$ & Enugu & Bitumen & $34.80(21.93-60.46)$ & $32.66(21.25-40.41)$ & $68.79(48.74-91.00)$ \\
\hline 5 & $\begin{array}{l}\mathrm{N}^{0} 6^{\circ} 25^{\prime} 47^{\prime \prime} \\
\mathrm{E} 007^{\circ} 28^{\prime} 00^{\prime \prime}\end{array}$ & Enugu & Coal 1 & $117.03(64.11-238.10)$ & $36.37(26.09-43.73)$ & $69.94(60.87-80.04)$ \\
\hline 6 & $\begin{array}{l}\text { N06 } 09^{\circ} 56^{\prime \prime} \\
\text { E007 } 29^{\prime} 07^{\prime \prime}\end{array}$ & Imo & Clay & $117.34(34.84-275.58)$ & $35.23(17.55-46.40)$ & $58.91(36.25-84.87)$ \\
\hline 7 & $\begin{array}{l}\text { N06 } 31^{\prime} 05^{\prime \prime} \\
\text { E007² } 26^{\prime} 34^{\prime \prime}\end{array}$ & Enugu & Gypsum & $136.0(87.40-161.82)$ & $49.46(41.24-53.65)$ & 67.25 (42.08-90.54) \\
\hline 8 & $\begin{array}{l}\mathrm{N}^{\circ} 6^{\circ} 23^{\prime} 53^{\prime \prime} \\
\mathrm{E} 007^{\circ} 27^{\prime} 15^{\prime \prime}\end{array}$ & Abia & Coal 2 & $82.58(25.67-174.22)$ & $22.47(15.38-27.12)$ & $55.31(37.99-64.36)$ \\
\hline
\end{tabular}


$\mathrm{E} 007^{\circ} 28^{\prime} 52^{\prime \prime}$

$10 \quad \mathrm{~N}^{\circ} 26^{\circ} 24^{\prime \prime}$

Anambra

Glass-

$48.02(21.00-70.10)$

$19.85(14.19-28.90)$

$189.11(74.18-588.93)$

$\mathrm{E} 007^{\circ} 27^{\prime} 45^{\prime \prime}$ sand

Overall Mean Value

$100.22 \pm 8.20$

33.15 \pm 3.31

19.63

$77.31 \pm 6.10$

Control (Mean)

28.60

35

25.92

Global Re

400

30

commended Value (UNSEAR 2010)

1

2

Table 2. Risk Estimate for workers in solid mineral mining site

\begin{tabular}{|c|c|c|c|c|c|c|c|c|c|c|c|}
\hline Variables & $\begin{array}{c}\mathrm{K}-40 \\
\left(\mathrm{~Bq} \mathrm{~kg}^{-1}\right)\end{array}$ & $\begin{array}{c}\text { Ra-226 } \\
\left(\text { Bq kg }^{-1}\right)\end{array}$ & $\begin{array}{c}\text { Th-232 } \\
\left(\text { Bqkg }^{-1}\right)\end{array}$ & $\begin{array}{c}\text { Raeq } \\
\left(\mathbf{B q ~ k g}^{-1}\right)\end{array}$ & $\begin{array}{c}\mathbf{D} \\
\left(\eta G y h^{-1}\right)\end{array}$ & $\begin{array}{c}\text { AEDE } \\
\left(\mu \mathbf{S v y}^{-1}\right)\end{array}$ & $\begin{array}{l}\text { AGED } \\
\left(\mu \mathbf{S v y}^{-1}\right)\end{array}$ & Hex & Hin & $I_{\gamma}$ & $\begin{array}{r}\text { ELCR } \\
\times 10^{-6}\end{array}$ \\
\hline Mean & 100.22 & 33.15 & 77.31 & 150.72 & 68.40 & 83.65 & 454.70 & 0.41 & 0.50 & 1.06 & 289.14 \\
\hline Median & 99.80 & 32.23 & 68.34 & 136.45 & 60.61 & 74.33 & 409.40 & 0.37 & 0.46 & 0.95 & 260.17 \\
\hline Mode & 34.80 & 19.88 & 44.30 & 87.51 & 38.96 & 48.26 & 263.62 & 0.24 & 0.29 & 0.61 & 167.24 \\
\hline Std. Deviation & 48.71 & 11.18 & 43.34 & 61.25 & 26.63 & 32.66 & 179.23 & 0.17 & 0.17 & 0.43 & 114.30 \\
\hline Skewsoilness & 0.19 & 0.61 & 2.53 & 1.81 & 1.73 & 1.73 & 1.71 & 1.81 & 1.18 & 1.80 & 1.73 \\
\hline Kurtosis & -1.14 & -0.33 & 6.94 & 3.67 & 3.34 & 3.34 & 3.26 & 3.67 & 1.28 & 3.64 & 3.34 \\
\hline Minimum & 34.80 & 19.88 & 44.30 & 87.51 & 38.96 & 48.26 & 263.62 & 0.24 & 0.29 & 0.61 & 165.45 \\
\hline Maximum & 179.15 & 52.65 & 193.11 & 300.13 & 133.00 & 161.80 & 879.51 & 0.81 & 0.86 & 2.10 & 559.31 \\
\hline
\end{tabular}

Table 3: Occupational Risk Estimate for workers in solid mineral mining sites 


\begin{tabular}{|c|c|c|c|c|c|c|c|c|}
\hline $\begin{array}{l}\text { Code } \\
\text { Name }\end{array}$ & $\begin{array}{l}\text { Mineral } \\
\text { Mined }\end{array}$ & $\begin{array}{l}\text { Ra-226 } \\
\left(\text { Bq kg } \text { kg-1) }^{-1}\right.\end{array}$ & $\begin{array}{l}\text { Th-232 (Bq } \\
\left.\mathrm{kg}^{-1}\right)\end{array}$ & $\begin{array}{l}\text { K-40 (Bq } \\
\left.\mathrm{kg}^{-1}\right)\end{array}$ & $\begin{array}{l}\left.\text { Dext }_{\text {exS }} \mathbf{y}^{-1}\right) \\
(\mathbf{m S v}\end{array}$ & $\begin{array}{l}D_{\text {inh }} \\
\left(\mathrm{mSv} \mathrm{y}^{-1}\right)\end{array}$ & $\begin{array}{l}\text { Ding (Sv } \\
\left.y^{-1}\right)\end{array}$ & $\begin{array}{l}\text { Total Eff. Dose } \\
\left(\mu \mathrm{Sv} \mathbf{y}^{-1}\right)\end{array}$ \\
\hline LS & Limestone & 30.63 & 48.87 & 155.68 & 0.97 & 0.50 & 0.10 & 51.30 \\
\hline CL1 & Coal & 36.37 & 69.96 & 117.03 & 0.99 & 0.71 & 0.13 & 72.40 \\
\hline $\mathrm{CY}$ & Clay & 35.23 & 59.10 & 117.34 & 0.97 & 0.01 & 0.12 & 61.70 \\
\hline $\mathrm{BN}$ & Bitumen & 32.66 & 69.44 & 34.80 & 0.73 & 0.71 & 0.12 & 71.42 \\
\hline IS & Ironstone & 20.45 & 47.98 & 54.26 & 0.53 & 0.48 & 0.08 & 49.26 \\
\hline $\mathrm{SC}$ & Silica & 52.64 & 97.72 & 179.15 & 1.47 & 0.99 & 0.18 & 10.11 \\
\hline KL & Kaolin & 31.80 & 70.04 & 81.65 & 0.82 & 0.71 & 0.12 & 72.02 \\
\hline GM & Gypsum & 49.49 & 67.25 & 136.04 & 1.30 & 0.69 & 0.15 & 71.14 \\
\hline GS & Glass-sand & 19.88 & 193.11 & 48.02 & 0.51 & 0.02 & 0.24 & 19.27 \\
\hline CL2 & Coal & 22.48 & 53.31 & 82.58 & 0.64 & 0.54 & 0.09 & 54.73 \\
\hline
\end{tabular}

\section{List of Figures}




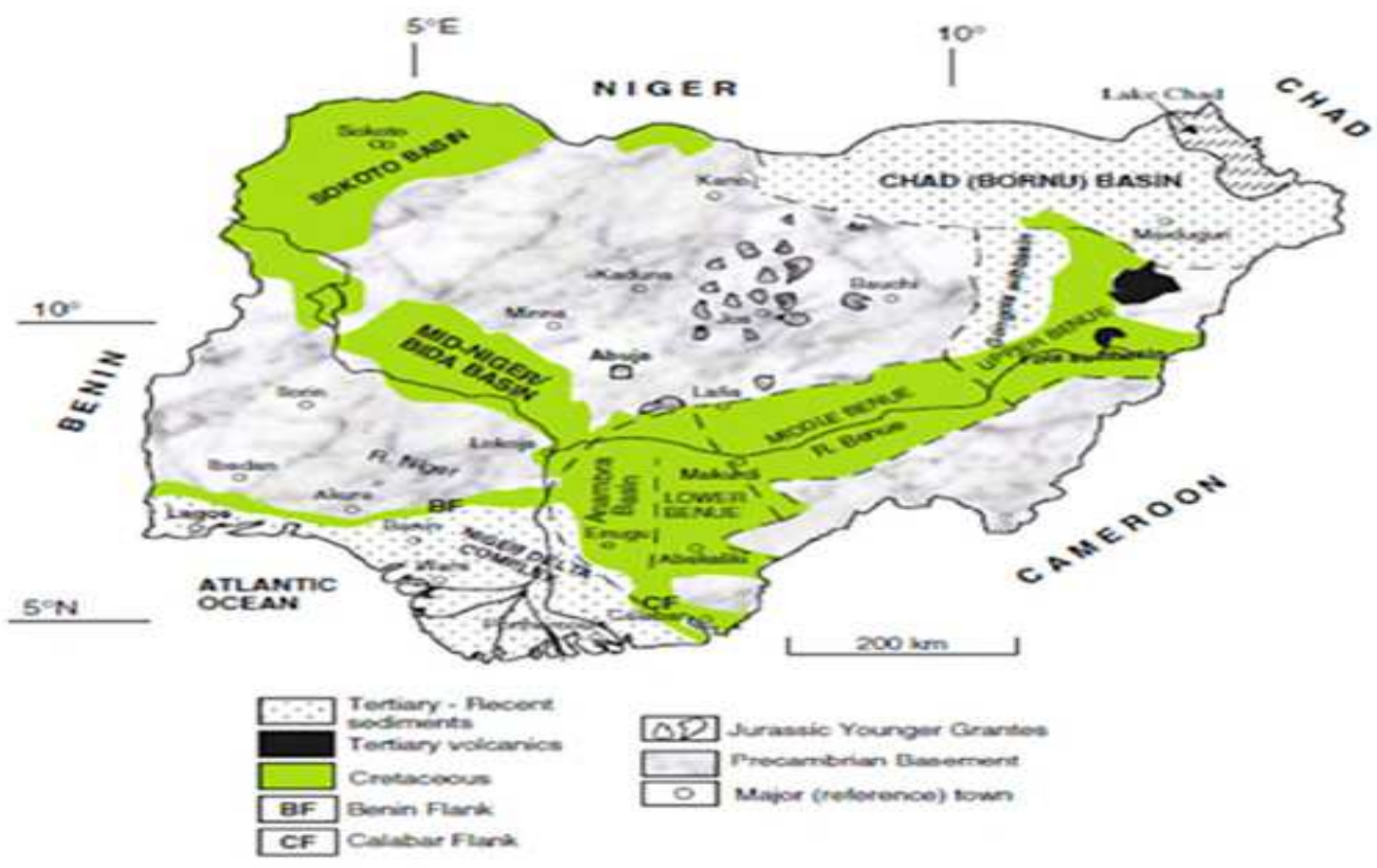

Figure 1: Geological Map of Nigeria showing the location of the area studied [59]

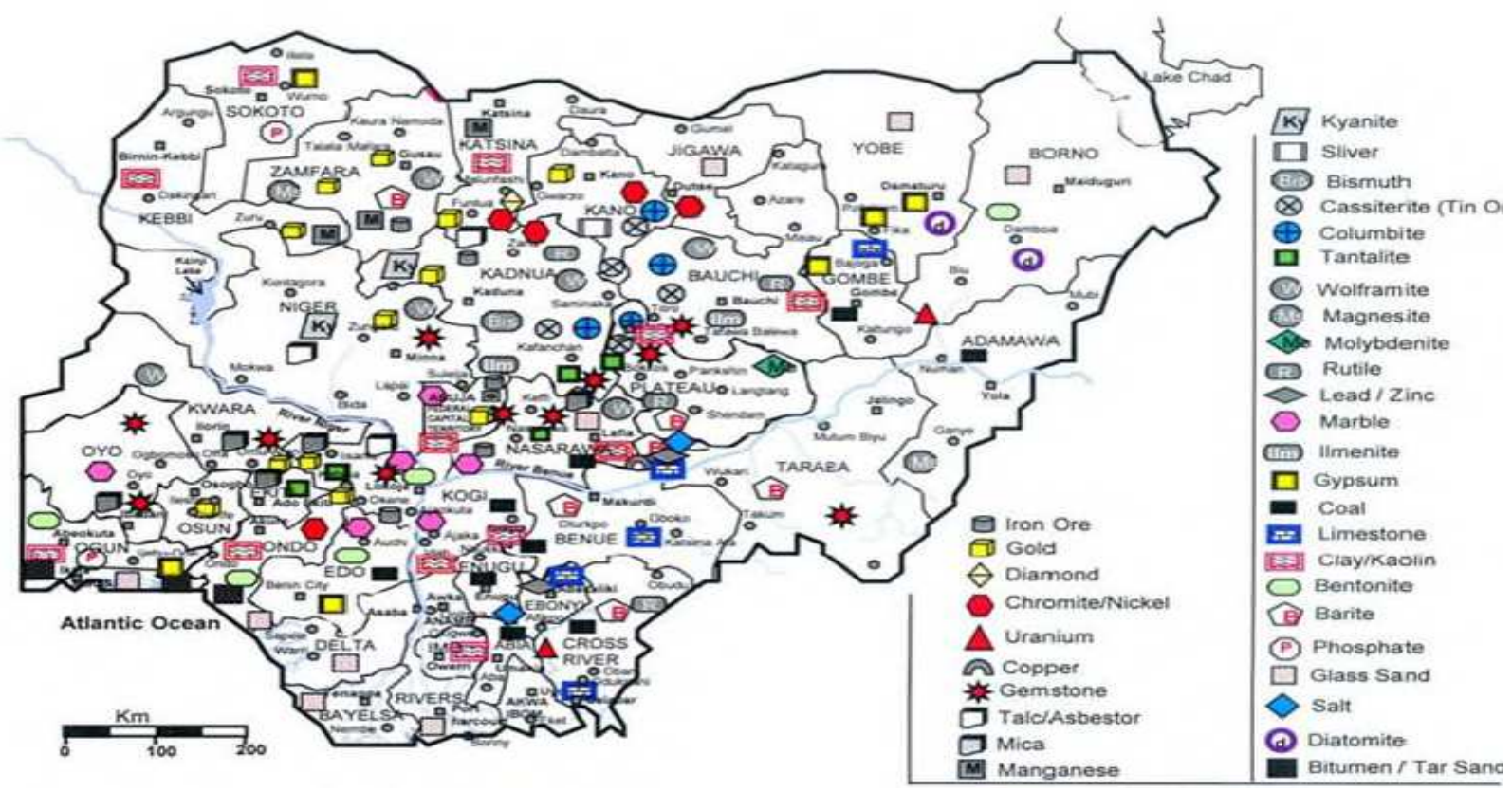

Figure 2: Solid Minerals and Locations Found in Commercial Quantity in Nigeria (Source:

Report of the Vision 2020 National Technical Group on Minerals and Metals Development)[60] 

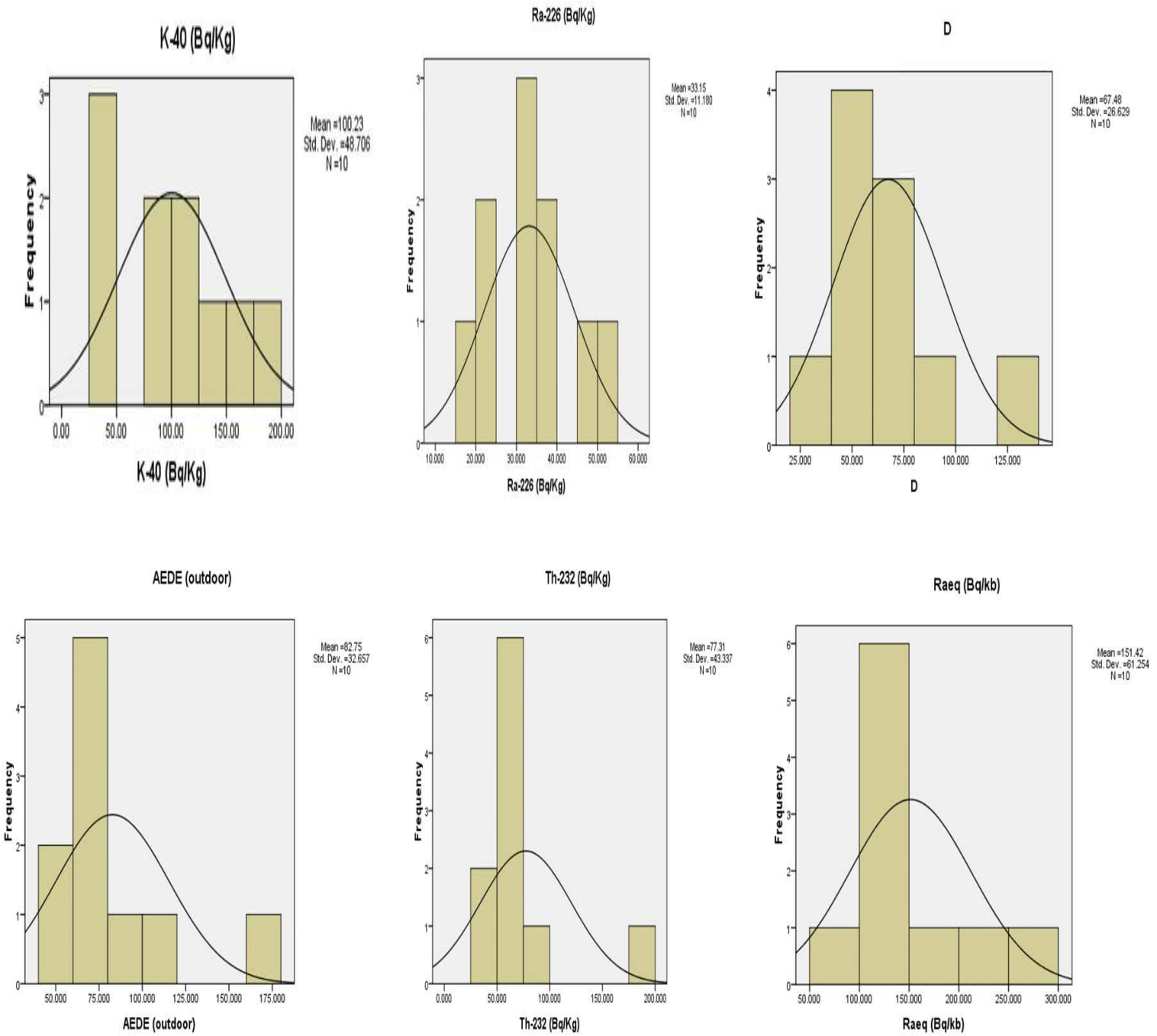

Figure 3: Histogram and Skewness plot of some Radiation parameters. 


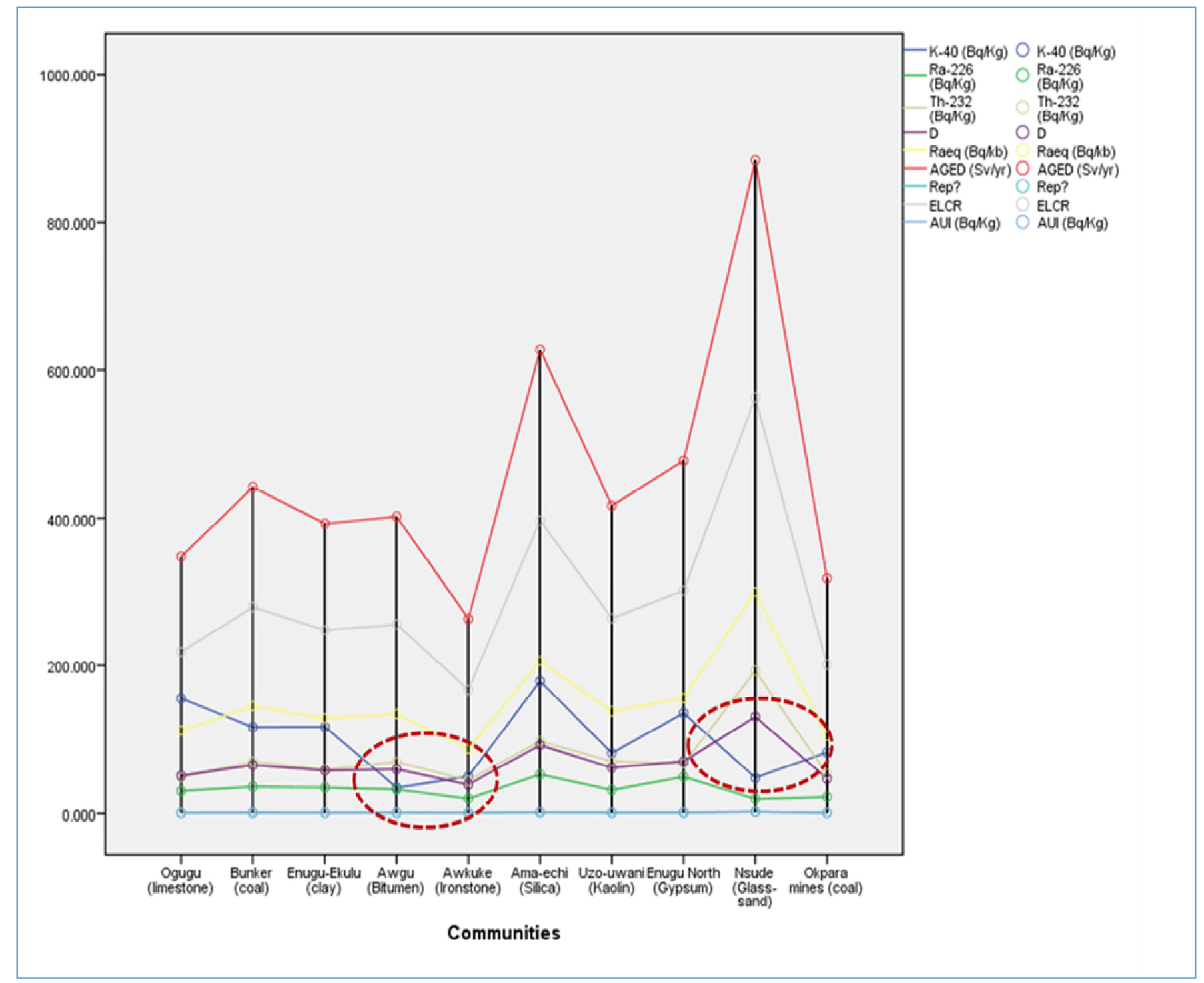

Figure 4: Sequence Chart of the Statistical Analysis. 


\section{Figures}

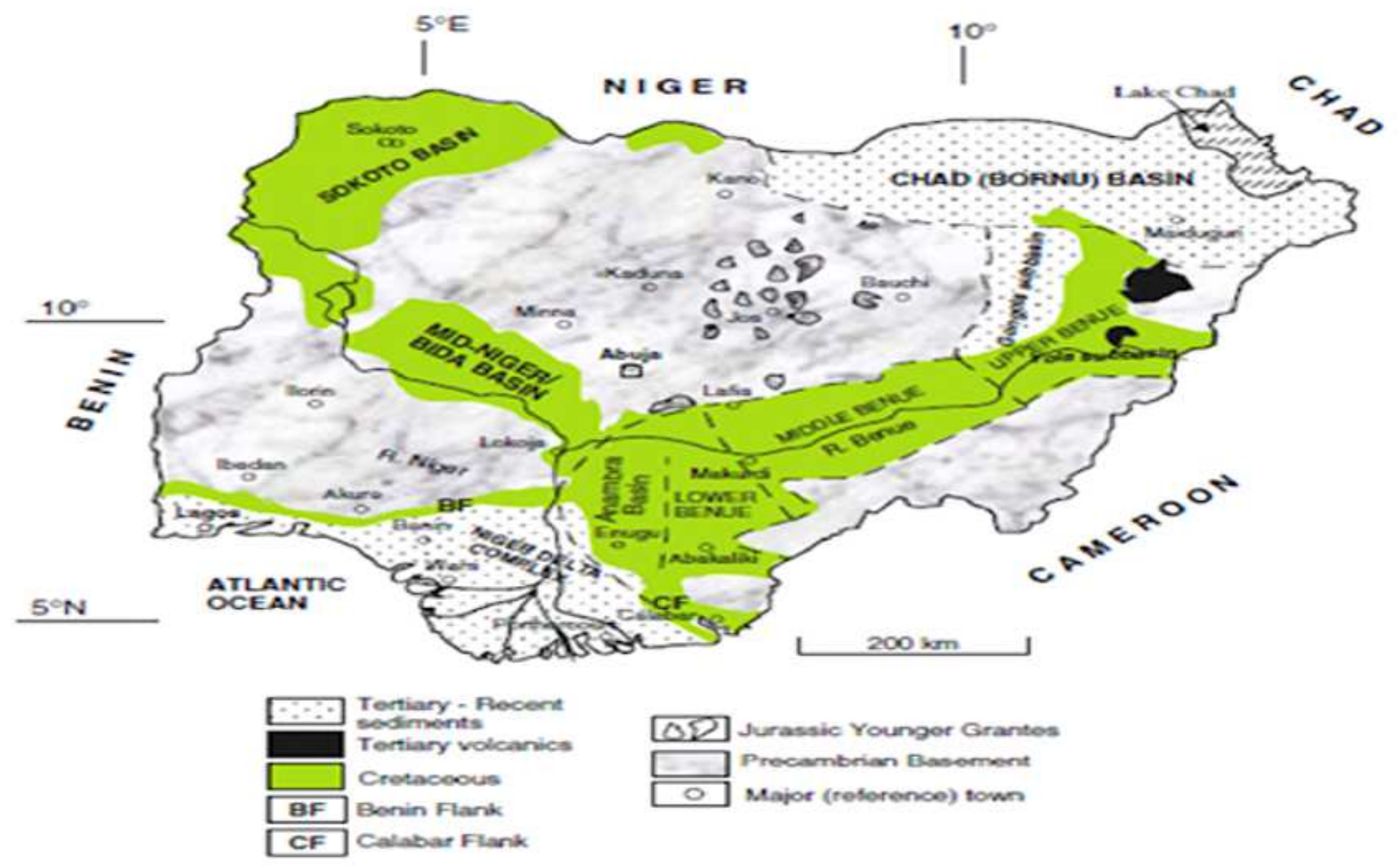

Figure 1

Geological Map of Nigeria showing the location of the area studied [59] Note: The designations employed and the presentation of the material on this map do not imply the expression of any opinion whatsoever on the part of Research Square concerning the legal status of any country, territory, city or area or of its authorities, or concerning the delimitation of its frontiers or boundaries. This map has been provided by the authors. 


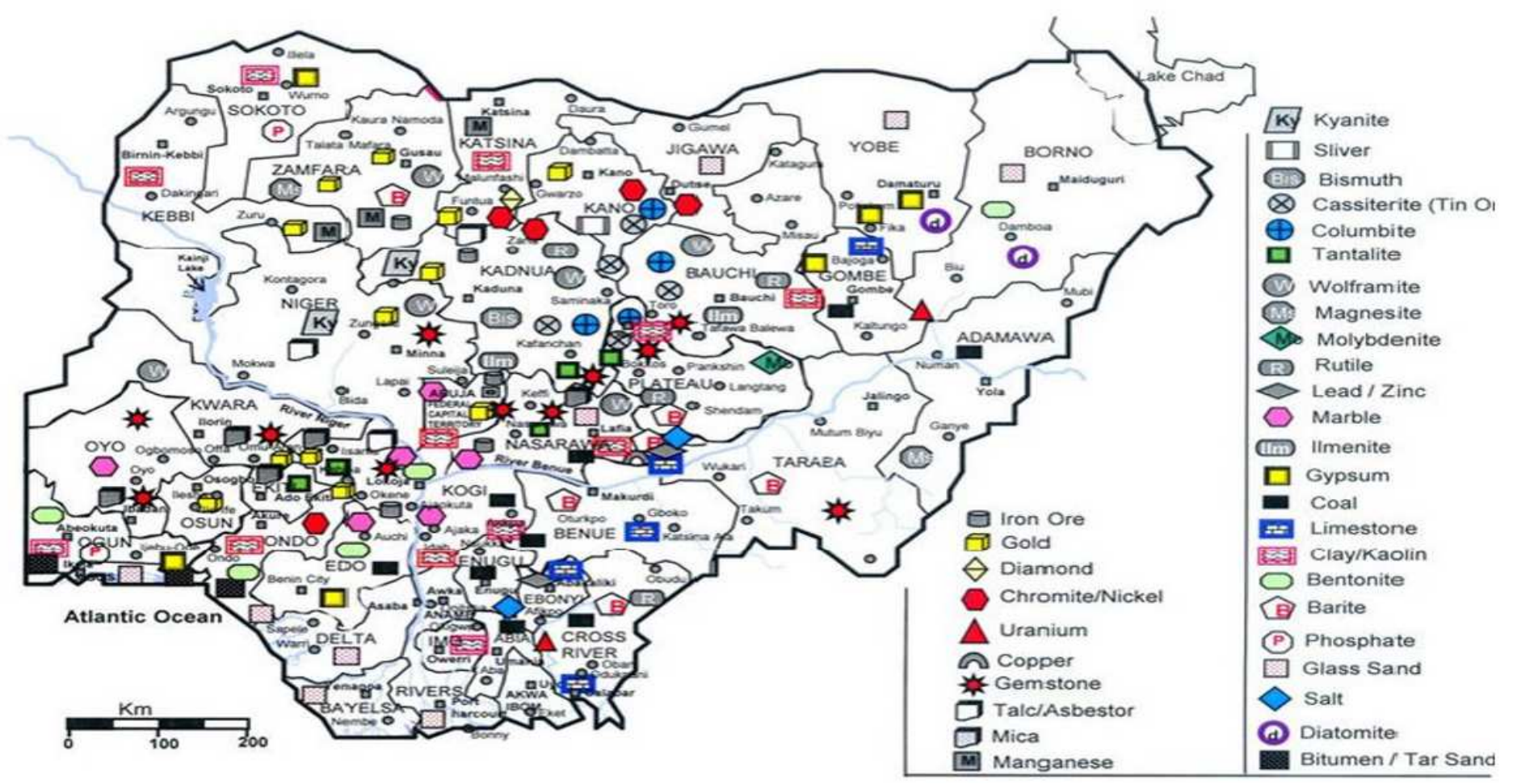

Figure 2

Solid Minerals and Locations Found in Commercial Quantity in Nigeria (Source: Report of the Vision 2020 National Technical Group on Minerals and Metals Development)[60] Note: The designations employed and the presentation of the material on this map do not imply the expression of any opinion whatsoever on the part of Research Square concerning the legal status of any country, territory, city or area or of its authorities, or concerning the delimitation of its frontiers or boundaries. This map has been provided by the authors. 
$K+40(B q K g)$

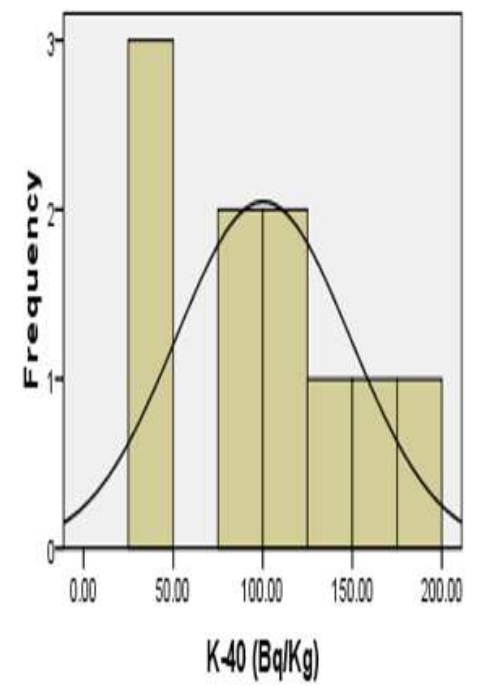

AEDE (outdoor)

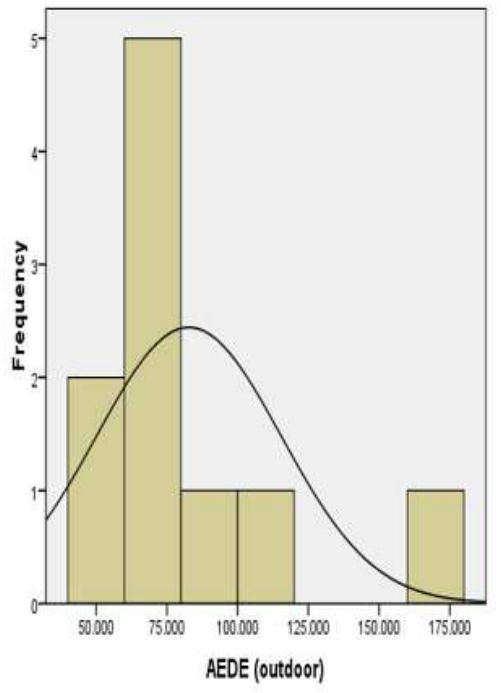

$\operatorname{Ra} \cdot 226(\mathrm{~Bq} \mathrm{Kg})$

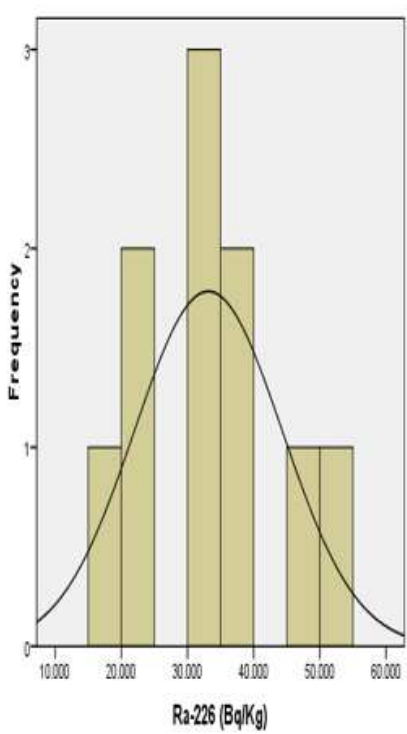

Th.232 (Bq/Kg)
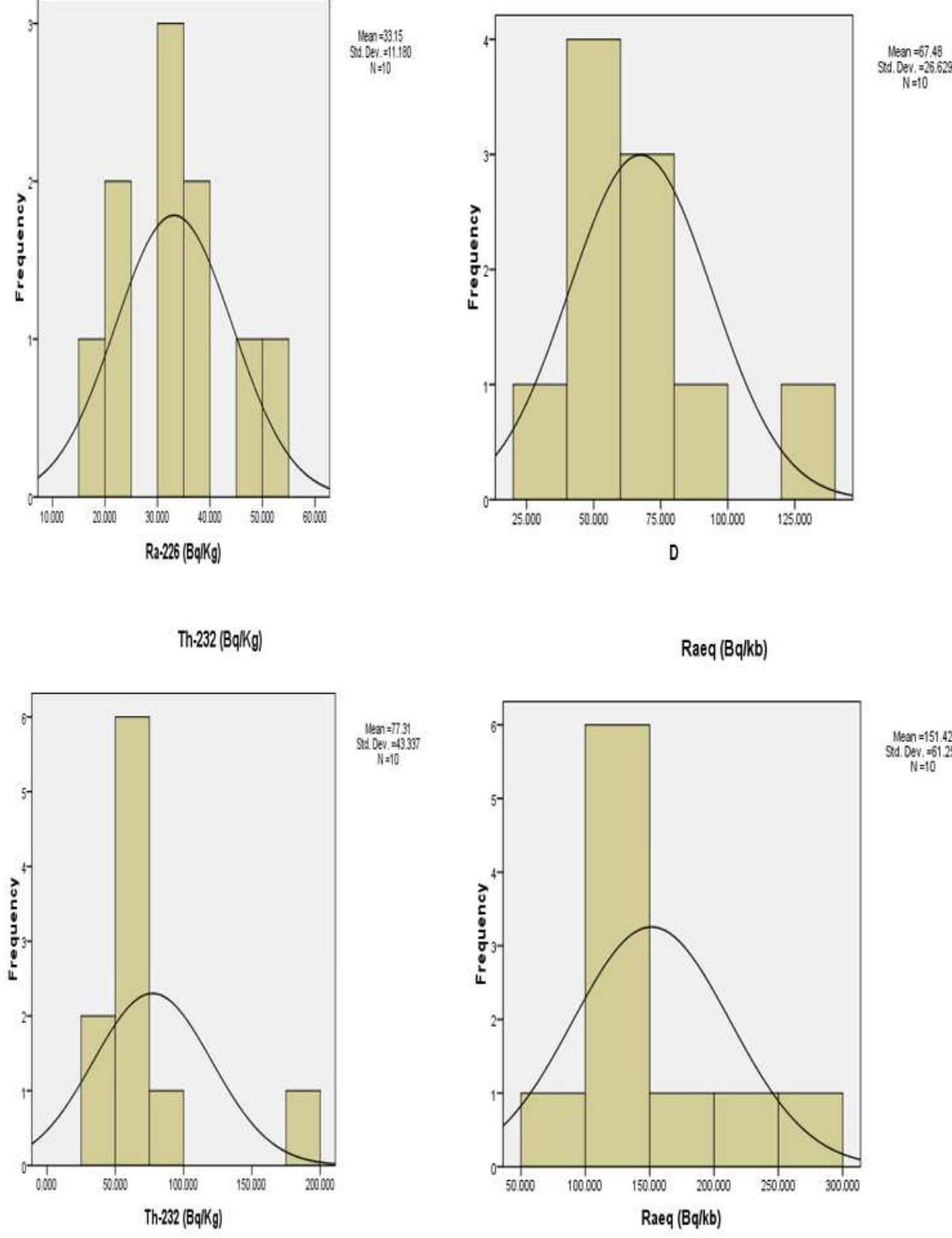

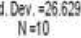

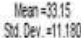

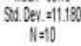
Sid Dev. $=48.706$ $N=10$
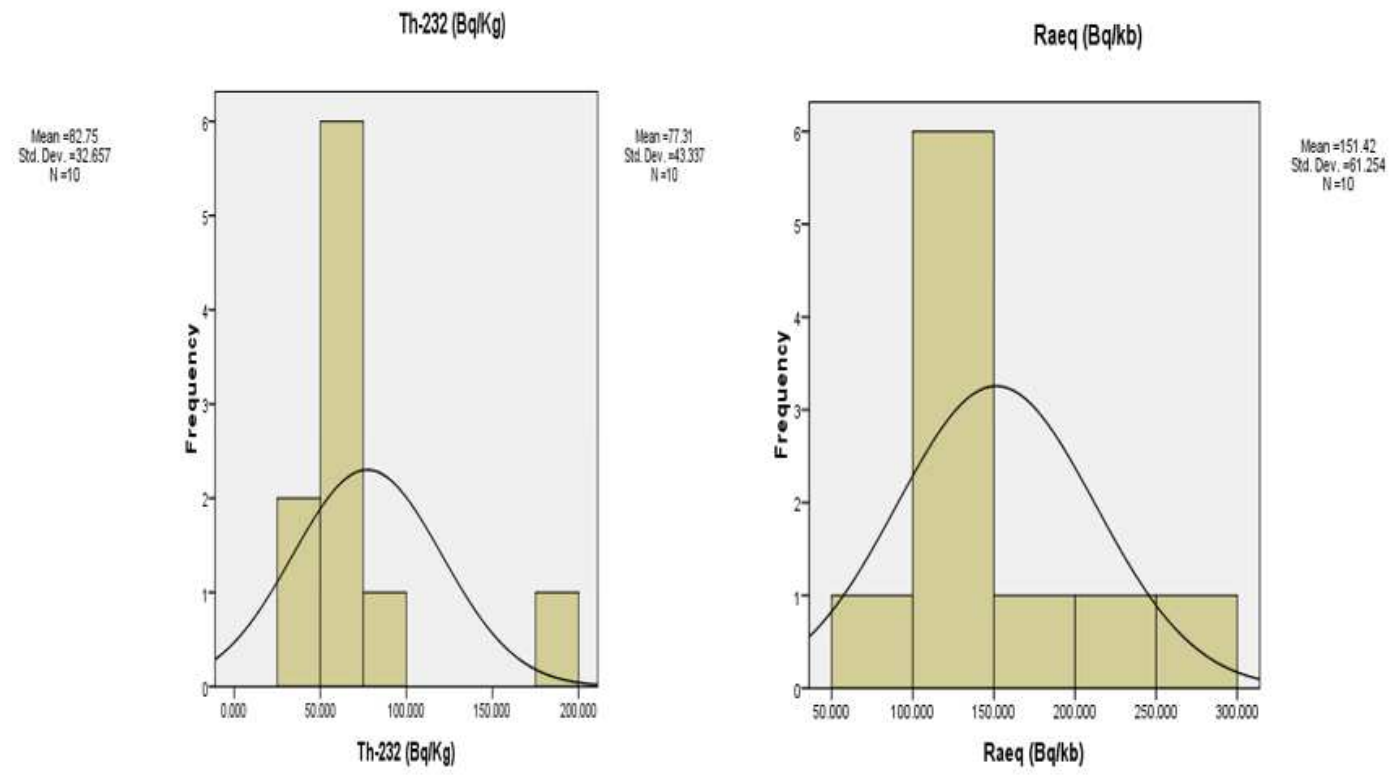

\section{Figure 3}

Histogram and Skewness plot of some Radiation parameters. 


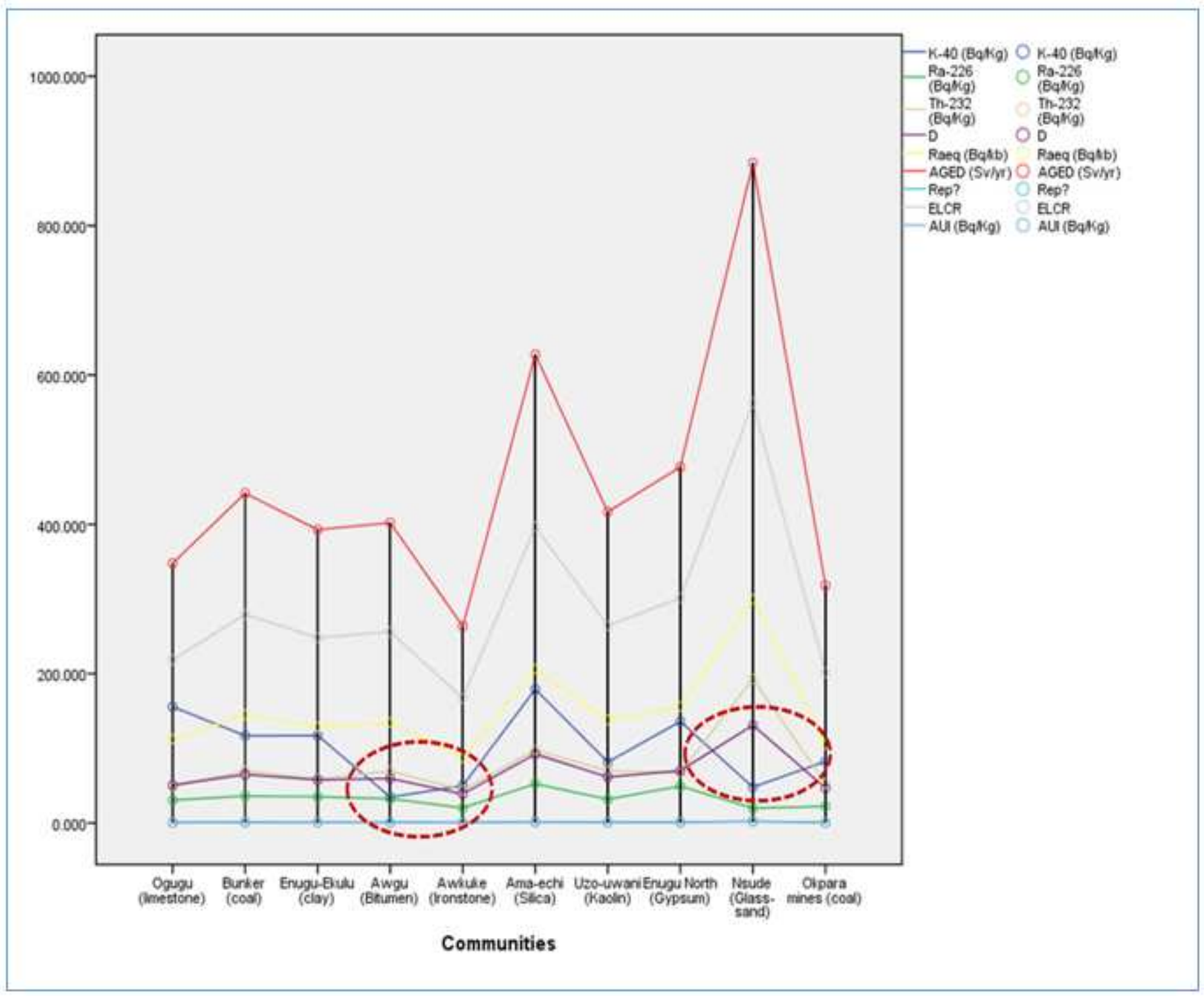

Figure 4

Sequence Chart of the Statistical Analysis. 